\title{
FOREIGN CORPORATIONS AND THE CULTURE OF TRANSPARENCY: EVIDENCE FROM RUSSIAN ADMINISTRATIVE DATA
}

\author{
Serguey Braguinsky \\ Sergey V. Mityakov \\ Working Paper 17731 \\ http://www.nber.org/papers/w17731
NATIONAL BUREAU OF ECONOMIC RESEARCH
1050 Massachusetts Avenue
Cambridge, MA 02138
January 2012

We thank Andrey Liscovich for outstanding research assistance. We are also grateful to Nicholas Bloom, William Dougan, Steven Klepper, Tom Mroz, and Kevin Tsui for valuable comments and suggestions. All the remaining errors are our responsibility. The views expressed herein are those of the authors and do not necessarily reflect the views of the National Bureau of Economic Research.

NBER working papers are circulated for discussion and comment purposes. They have not been peerreviewed or been subject to the review by the NBER Board of Directors that accompanies official NBER publications.

(C) 2012 by Serguey Braguinsky and Sergey V. Mityakov. All rights reserved. Short sections of text, not to exceed two paragraphs, may be quoted without explicit permission provided that full credit, including $(\odot)$ notice, is given to the source. 
Foreign Corporations and the Culture of Transparency: Evidence from Russian Administrative

Data

Serguey Braguinsky and Sergey V. Mityakov

NBER Working Paper No. 17731

January 2012

JEL No. K42,P37

\begin{abstract}
$\underline{\text { ABSTRACT }}$
Foreign-owned firms from advanced countries carry the culture of transparency in business transactions that is orthogonal to the culture of hiding and insider dealing in many developing economies and economies in transition. In this paper, we document this using administrative data on reported earnings and market values of cars owned by workers employed in foreign-owned and domestic firms in Moscow, Russia. We examine whether closer ties to foreign corporations result in the diffusion of transparency to private Russian firms. We find that Russian firms initially founded in partnerships with foreign corporations are twice as transparent in reported earnings of their workers as other Russian firms, but they are still less than half as transparent as foreign firms themselves. We also find that increased links to foreign corporations, such as hiring more workers from them, raise the transparency of domestic firms. An important channel for this transmission appears to be the need to keep official wages and salaries of incumbent workers close to wages domestic firms have to pay to their newly hired workers with experience in multinationals.
\end{abstract}

Serguey Braguinsky

Department of Social and Decision Sciences

and Heinz College,

School of Public Policy and Management

Carnegie Mellon University

Pittsburgh, PA 15213

sbrag@andrew.cmu.edu

Sergey V. Mityakov

John E. Walker Department of Economics

Clemson University

222 Sirrine Hall

Clemson SC 29634

smityak@clemson.edu 


\section{Introduction.}

The role of foreign capital in promoting economic transformation in developing countries and countries in transition has received a lot of attention in the literature. So far this attention, however, has almost entirely been limited to its role in the diffusion of knowledge (Branstetter [2006], Keller and Yeaple [2009]) and/or the transfer of more efficient managerial practices (Bloom et al. [2010, 2011], Görg et al. [2007], Sabirianova Peter et al. [2005]). Another and potentially even more important role of foreign capital is in creating and transmitting a culture of transparency in economic transactions.

Imagine being approached by someone who has a mutually beneficial business proposal that looks really attractive. The only problem is that the potential partner insists that everything is based on "a handshake," with no formal written arrangements, money changing hands in cash, and no paper traces left of any transactions. If your economic culture is rooted in a Western-type economy you will probably walk away from such a proposal. But it comes as the most natural way of doing business for economic agents whose culture is rooted in decades of hiding all that can possibly be hidden from the government's "grabbing hand" (Shleifer and Vishny [1998]).

The most damaging aspect of the culture of hiding from an economic point of view is that even though private benefits may outweigh private costs, hiding entails large efficiency costs for the market overall, such as market segmentation, high transaction costs of doing business outside of a narrow range of trusted partners, limited opportunities for outside investment, etc. (e.g., Shleifer and Vishny [1997], Braguinsky [1999], Braguinsky and Myerson [2004]). If the activity of multinational corporations can somehow help transform the local corporate culture towards more transparency of business transactions, this would imply a major role of foreign capital in fostering economic efficiency in developing countries and countries in transition.

In this paper we address this question by using a unique dataset available in Moscow, the capital city of Russia and the center of its economic life. The culture of hiding in which most Russian firms operate has been documented through survey data and anecdotal evidence in several past studies (e.g., Johnson et al. [2000], Yakovlev [2001]) as well as in our own recent study (Braguinsky, Mityakov, and Liscovich [2010], hereafter BML). The first thing we do in the current paper is to confirm the conjecture 
about much higher transparency of wages and salaries paid by multinationals. We find that the employees' earnings reported by foreign-owned firms are on average four times higher than in domestic firms for the same car values, controlling for various other characteristics such as firm size and sector of economic activity as well as individual characteristics.

The fact that foreign-owned firms are much more transparent in labor contracts than domestic companies has important implications in its own right. In particular, it indicates that conventional measures of the labor productivity gap between multinationals and local companies (which inevitably rely on reported output per worker or reported wages) should be taken with a grain of salt. It seems that a lion's share of actual employee compensation in domestic firms is paid outside of the formal reporting system ("black" as opposed to "white" wages, to use the term widely employed among Russian workers themselves). ${ }^{1}$

While the immediate role of multinationals in increasing labor productivity may thus be less than measured by conventional methodology, they may nevertheless play an important (and so far understudied) role in improving the overall efficiency of the economy if they can spread the culture of transparency to domestic firms. Our data allow us to examine whether links to multinationals do indeed have this effect.

To address this question, we first identify in the data private Russian companies with a non-zero fraction of workers with experience in multinationals (hereafter, "foreign-related firms," FRF). Our estimates, controlling for employer-individual-level fixed effects, indicate that the impact of hiring more workers from the multinationals on transparency of other workers in FRF is positive and significant both statistically and economically. An increase in the fraction of workers hired from multinationals by one standard deviation is associated with 20 percent increase in transparency among workers who stayed employed in private domestic companies. Notably, we find no such effects for employees of state-owned establishments.

\footnotetext{
${ }^{1}$ Such payments are often supplemented by employees stealing from the firms they work for; and the (net of costs) value of stolen goods, services and working time should be included in total employee compensation to make efficiency comparisons meaningful. Our methodology allows us to capture both of the above sources of unreported compensation. We benefited from discussions with Nicholas Bloom.
} 
To better understand the mechanism that could account for these patterns, we collected the data on founding backgrounds and subsequent company histories for a large sample of FRF from their websites and other sources. One of the most striking findings is that Russian private firms that were founded in partnership with foreign-owned firms ${ }^{2}$ offer about twice as transparent labor contracts as other FRF, even when controlling for the fraction of workers with experience in multinationals. They thus locate almost exactly "in-between" the two opposite corporate cultures. By the time our data coverage starts, most of these firms had long outgrown their initial stage and were owned and operated entirely by their Russian owners, while producing and selling their own products and services instead of just acting as distributors. Nevertheless, the high impact of "cultural influence" from multinationals experienced at the time they were founded is very clearly detectable in the data.

Apart from direct influence as in cases above, we tried to look for a mechanism that could make domestic companies more transparent when they increase hiring from multinationals. One possible channel is "vertical spillovers," where business practices of companies change with changes in top managerial personnel (e.g., Bertrand and Schoar [2003]). This conjecture led us to look for changes in transparency that might be driven by hiring high-ranking employees and managers from foreign-owned firms but we did not find much empirical support for this hypothesis, at least in the overall data.

Instead, we find empirical patterns that can be described as "horizontal" spillovers of transparency. The transparency increase is larger for employees who are closer to newly hired workers from multinationals in the job quality space. We hypothesize that to prevent disruption in the workplace, domestic firms might engage in "benchmarking" of earnings of incumbent employees to the earnings they have to pay to workers recruited from multinationals. Interestingly, we do not find support in the data for the conjecture that most workers moving from multinationals to domestic firms are more reluctant to accept employment contracts with a large fraction of "black wages," although we do find some support for this in employers with the closest ties to multinationals.

\footnotetext{
${ }^{2}$ Such as joint ventures with foreign investors holding a minority share, or authorized distributors of foreign producers.
} 
Our paper is related to several strands in the literature. The development economics literature investigated the impact of foreign direct investment on economic performance of companies in recipient countries. Existing attempts to assess this impact came up with mixed results: Aitken and Harrison [1999] and Smarzynska [2004] present evidence of positive spillovers from foreign firms presence in the industry, while Aitken, Harrison, and Lipsey [1996] find no or even negative effects. More recently, availability of employee-employer matched studies allowed for more detailed analysis through the channel of labor mobility; see, e.g., Gorg and Strobl [2004], and Balsvik [2011].

Our paper follows this empirical approach. However, our conceptual focus is complementary to the existing literature. Rather than trying to estimate productivity spillovers from foreign firms' presence in the industry we focus on the role of multinationals in spreading the corporate culture of transparency, which affects reported earnings. We argue that without distinguishing between reported vs. true earnings comparing wages in domestic and foreign firms is likely to be misleading.

Our paper also contributes to the growing literature on the shadow or hidden economies (see Schneider and Enste [2000] for a survey). Most of the papers in this field rely on indirect aggregate indicators like electricity consumption (Alexeev and Pyle [2003]), share of cash in transactions (Tanzi [1983]), or on survey data with self-reported consumption and incomes (Pissarides and Weber [1989], Gorodnichenko et al [2009]). ${ }^{3}$ Our approach which employs administrative records allows us to obtain more precise and disaggregated estimates of hiding and its determinants.

The rest of the paper is organized as follows. In Section II we present an overview of the system of hidden earnings in the Russian economy and briefly discuss some of the previous findings in the literature. In Section III we describe the data and the construction of our sample. We also lay out the empirical model used in our estimations. Section IV presents our findings concerning relative transparency of multinationals and domestic Russian firms and also how close ties to multinationals play out in the transmission of transparency culture from multinationals to domestic firms. Section V examines possible mechanisms for such transmission and also contains some robustness checks. Section VI concludes.

\footnotetext{
${ }^{3}$ See Hanlon et al. [2007] and DeBacker et al. [2011] for notable exceptions.
} 


\section{Hidden Earnings and Multinationals: an Overview}

Most hidden earnings in Russian companies appear to be "black wages," which are either envelopes with actual cash handed to workers by the management or more elaborate schemes, where compensation is disguised as, for instance, an insurance policy or a foreign exchange transaction on which the employer deliberately takes a loss. ${ }^{4}$ Firms benefit because they evade the payroll tax, as well as the sales tax (in case of unregistered cash transactions) or the profit tax (when "black wages" are disguised as losses on investment). "Black" wages can also be used by the management to reward or punish employees with impunity from labor regulations and laws. The system of "black wages" is thus part of the peculiar culture of cronyism and power harassment in the workplace, arguably inherited from the final decades of the decaying Soviet economy.

An important part of hidden earnings also appears to be comprised of employertolerated theft. The Soviet Union in its heyday would literally execute an individual who stole just a handful of potatoes from the "collective" field. In the Soviet Union during its final years, the "parallel economy" dealers were stealing with impunity whole cargo trains whose movements were supposedly monitored at the Politburo level (Vaksberg [1992], Braguinsky and Yavlilnsky [2000]), and ordinary workers were not far behind. A bartender would steal liquor, a butcher would steal meat, etc. The culture of stealing was not limited to the trade and services sector (although it was certainly relatively more prevalent there) but was also common in manufacturing firms (where employees would steal raw materials or use their workplaces for side jobs), transportation services (where a taxi driver would take a client without turning on the meter), and so on.

This culture of stealing was carried over to the post-communist economy where many new owners, even in genuinely private firms, were by and large either incapable or unwilling to change it. Instead, the value of stolen goods, utilities and time at work is implicitly included into the labor contracts, thus reducing the official compensation firms

\footnotetext{
${ }^{4}$ Even a casual web search comes up with at least a dozen sites that openly discuss the costs and benefits of "white" versus "black" wages from the employers' and employees' perspective, compare various schemes employed by firms, etc., e.g., http://mirsovetov.ru/a/miscellaneous/employment/salary-black-white.html, http://trudprava.ru/index.php?id=1423. For a good source in English see Yakovlev [2001]. See also BML, Appendix 8.
} 
have to pay to their employees. And, just as with "black wages," employer-tolerated theft also gives a lot of discretionary powers to managers over their workers (you behave and I will look the other way, you don't behave and I will have you arrested and prosecuted). ${ }^{5}$

Even though the system of "black wages" (explicit or implicit) as described above is clearly inefficient, once the culture that accepts it is firmly entrenched, it becomes hard to dislodge. From a worker's perspective, the benefit of a non-transparent labor contract with a large "black" component or implicitly tolerated workplace theft is, first and foremost, saving on the personal income tax and also on the part of the payroll tax that would otherwise be shifted to wages. Just as in "corruption with theft" (Shleifer and Vishny [1993]) the system aligns the interests of the worker and the employer, with the loser being the state (and overall economic efficiency). The main individual cost of "black wages," on the other hand, at least in an environment where this culture is well entrenched and the risk of prosecution is very low, would be of a psychological nature, especially high for those who want to be law-abiding citizens or for those who have low tolerance for arbitrary behavior by the management. ${ }^{6}$

The corporate culture brought into Russia by foreign capital is orthogonal to the above. First, foreign-owned firms come from an environment where transparent labor contracts are the norm and "black wages" are generally balked at by both employers and employees. Even though some foreign-owned firms may actually be not averse to playing by the prevailing rules of the game in their destination countries (there is both anecdotal evidence and evidence in our data that some foreign-owned firms do pay at least some part of compensation in unregistered cash), their ability to embrace those rules is still severely limited. Foreign-owned firms, especially large multinational corporations,

\footnotetext{
${ }^{5}$ While many explanations were advanced for the fate suffered by the former richest man in Russia Mikhail Khodorkovsky (who has been in jail since 2003), we find the explanation along the lines above to be the most likely one. Khodorkovsky was probably guilty of at least some of theft and tax evasion charges he was convicted on, but so were many other "oligarchs" who have not suffered his fate. The difference seems to be that Khodorkovsky did not "behave." Thus, the culture we are talking about is truly ubiquitous in Russia even today, going all the way to the highest echelons of the hierarchy.

${ }^{6}$ There is also the cost of forgoing employers' contributions to the social security fund, which will be felt more by older workers who are closer to retirement.
} 
must be conscious of their reputation, both in their home countries and world-wide. They can also be subject to litigation and punitive sanctions in their home countries for breaking the laws in other countries and they commonly lack the necessary connections to escape the scrutiny of the Russian tax authorities. On top of that, few if any managers of multinational corporations are likely to tolerate employee theft. In efficient labor markets, this means that the "white wages" they have to pay to their employees have to be much higher than the "white" component of wages paid by their domestic counterparts.

The presence of multinationals expands the menu of choices available to workers in the domestic economy. In the absence of an alternative system, there might be no chance for workers whose personal costs of non-transparent labor contracts are high to change the environment without suffering serious economic penalties. For example, refusing to accept "black cash" will result not only in forgoing a large part of the actual compensation but may very well result in losing the job itself, and the same is true about refusing to steal while working for an employer where everybody else is stealing.

If, however, foreign-owned firms just play the role of offering a more palatable type of employment and rewards to workers with intrinsic preferences for transparency, their role in changing the overall corporate culture in the recipient economy will be limited. Multinationals will in this case simply be small islands of higher transparency (and higher efficiency) amidst the sea of other firms with low efficiency and widespread "black wages." Such islands will help workers who gain access to them to acquire better skills, and will contribute to both their material and psychological well-being, but they will not make much of a difference in how the majority of the domestic workforce goes around doing their business. After all, the fraction of genuinely foreign-owned firms in total employment in our data for the Russian capital city of Moscow is less than 2 percent. To have a real impact on the recipient economy as a whole, more transparent culture of multinationals should be somehow transmitted to domestic firms. Of course, the same is also true of technology diffusion and the spread of better management practices.

One possibility that we entertain in this paper is that experience of working for a multinational may lead some workers to at least partially acquire the culture of transparency which they then carry over to domestic firms when they move into them. Of course, it is also possible that those who quit the foreign sector do so (or are fired) 
because they failed to embrace the culture of transparency. We spend a lot of effort to tease out these possibilities in the data and overall it seems that the prevailing culture of hiding in domestic firms wins, in the sense that workers who move from multinationals to domestic firms are less transparent than other multinational employees even while working for multinationals. They become all but indistinguishable in terms of the transparency of their wages and salaries from the rest of the domestic workforce right after the move.

We do find, however, rather strong evidence that serious ties to multinationals (such as working with foreign capital at the time the firm was founded, or an increase in the number of workers hired from multinationals) positively affect the transparency of domestic firms that enter into such ties. This provides us with some hope that more penetration of foreign capital and closer links between foreign-owned and domestic businesses may over time change the situation for the better.

\section{Data and Empirical Methodology}

\subsection{Data Sources and Sample Construction}

Our data come from two main sources. The first is five administrative databases of incomes between 1999 and 2003. The databases, which contain information allowing us to identify both income sources (employers) and income recipients (individuals), are official records of all payments and withheld taxes generated by all income sources registered in Moscow. ${ }^{7}$ As is usual with administrative data, parts of the data were of poor quality and had to be eliminated. Specifically, we eliminated cases where individuals' names contained abbreviations, obvious typos or non-alphabetic characters, and the data where we did not have information on dates of birth or addresses. We also dropped all observations on individuals who appeared to be present more than once in the

\footnotetext{
${ }^{7}$ These databases somehow became publicly available in the mid-2000s and have been reproduced and distributed on CDs as well as over the internet, presumably targeting demand from marketing agencies. Several previous studies employed these data, stripping them of all individual identifying information to protect privacy, for research purposes (Guriev and Rachinsky [2006], Braguinsky et al. [2010]) and we follow this practice here. The 2004 database is also available but we did not use it because the spread of consumer credit that started in Moscow in that year might compromise our identification strategy.
} 
income database in a given year. Random testing revealed that in about 10 percent of such cases, the second, third and so on entries were exact duplicates of the first one (sometimes with a trivial correction of a typo), so including those would have resulted in counting incomes of such individuals more than once. This procedure also eliminated individuals with multiple income sources in a given year, which could have complicated the interpretation of our estimates as explained below.

The total number of observations for five years of administrative income data we were left with after the above procedure was $26,889,790(4,329,337$ in $1999,5,790,422$ in 2000, 5,946,298 in 2001, 4,592,606 in 2002 and 6,231,127 in 2003). This corresponds to about 60 percent of all raw entries contained in the five databases. We then used individual-identifying information contained in the data to match the same individuals across income databases in different years. We were able to match 19,201,689 observations as pertaining to the same individual in at least two different years. For the remaining 7,688,101 observations (about 29 percent of the total) we were not able to obtain repeated observations in different years, so we treat them as separate individuals present in the income databases in only one year and employ them for cross-section analyses only. Appendix 1 explains the steps used in the matching procedure and also provides more details about the number of individuals matched across various years.

Our second source of the data is the 2005 auto registration database, which is a snapshot of cars and their owners as of April of that year that also contains full vehicle histories. We used the vehicle identification number (VIN) to trace its history of owners. We eliminated all vehicles owned not by individuals but by legal entities, as well as trucks, mini-buses, motorcycles and other non-passenger cars (even if registered in the names of individual owners). We then used the information about the make, model and year to impute the market value of the car in a given year according to a standardized procedure, described in Appendix 2.

Individual identifying information contained in the auto registration database was used to match car owners to their income and tax records in the income databases described above. We were able to match 2,913,359 individuals who owned at least one car in 2005 to their corresponding entries in at least one of the income databases above. 693,366 (23.8 percent) of them owned cars with missing information about the vehicle's 
VIN, making it impossible to trace their history of ownership. We elected to eliminate such car owners as well as all cars with missing VINs from our analysis. ${ }^{8}$ We also dropped the bottom 20 percent of observations with the lowest market value of the cars (about $\$ 1,200$ or less) out of concern that such old and highly depreciated cars could not serve as a proxy for true earnings for the period in our data. We experimented with other reasonable cutoffs and the estimation results were similar.

To address the issues of corporate culture we needed to classify employers by ownership and sector of activity. The total number of Moscow legal entities in our sample containing matched car ownership-incomes data is 190,965. Unfortunately, we could not rely on an automated procedure to assign ownership and sector to most of them. One especially serious problem from the perspective of this study is that many firms that are officially registered as foreign-owned are actually firms owned by Russian capital through paper offshore companies. These needed to be separated from legitimate foreign-owned firms, and the only way to do it was to examine each potential foreignowned entity manually. Furthermore, it is well known that a large number of firms registered in Moscow are shell paper companies created (and dissolved shortly after) for the sole purpose of money laundering. Not only will such firms not be producing anything for the market, they will often have no one actually employed in them, instead using stolen or borrowed identities for registration purposes. ${ }^{9}$ If too many of those paper companies found their way into our sample, any comparisons between the transparency of multinationals and Russian firms could be seriously compromised.

We therefore elected to start our analysis with 13,263 income-generating employers (legal entities) that we had already classified for our previous study (BML), in which we used a random sample of car owners actually residing and legitimately employed in Moscow for all five years 1999-2003. We used employer identification numbers and names and addresses contained in the income databases to retrieve

\footnotetext{
${ }^{8}$ Since most of the cars with missing VINs are old and largely depreciated, the total estimated value of cars in our sample drops by less that 14 percent as a result of eliminating cars with bad VINs. We also confirmed that retaining those cars and their owners does not affect any of the results presented below.

${ }^{9}$ An official for the Russian Federal Tax Service estimated that 2 out of 5 firms registered in Moscow were such "one-day" entities, as they are called in Russia - see http://www.delpartner.ru/?act=n\&id=33.
} 
information from open sources about ownership and the sector of economic activity of all those employers.

Our classification procedure identified 10,179 out of 13,263 employers to be private, non-foreign firms, 2,793 to be government agencies or state-owned firms, and 291 to be genuine (not offshore-type) foreign-owned firms. Given that our focus in the current paper is on investigating possible corporate culture spillovers between foreignowned firms and Russian firms related to them, we decided to add more firms that would be hiring workers with experience in multinationals. For this purpose, we traced the movements of individuals who worked for the 291 foreign-owned employers classified in the previous stage, and obtained information about ownership and sector of economic activity for all their other employers over the five observation years. This resulted in adding 1,137 more employers, 677 of them Russian private firms, 179 government agencies and state-owned firms and 281 foreign-owned firms. In the process we also collected some additional information about those "foreign-related" firms which will be used below. In the end, the total number of distinct employers for which we have information about ownership and sector of economic activity is 14,000, 10,856 of them private Russian firms, 2,972 government agencies/state-owned firms and 572 foreignowned firms. See Appendix 3 for the details of the breakdown of the data by sectors of economic activity.

The number of observations where individuals received incomes from these 14,000 employers amounts to roughly half of all observations in the data (13.6 million out of 26.9 million of all observations in the five income databases and 1,074,247 out of 2,219,933 among matched observations across income and car ownership databases). Thus, even though the number of employers for which we have information about ownership and sector of activity is relatively small (just about 7 percent of all officially registered legal entities present in all five income databases), we in fact have observations on 50 percent or more of all legitimate (that is not shell) companies in Moscow in terms of employment. Notably, more than 70 percent of employers used in this paper are present in all five income databases, while less than 10 percent show up in just one year (which in general might be a tell-tell sign of a shell company). ${ }^{10}$ Appendix 3 contains

\footnotetext{
${ }^{10}$ We checked the robustness of all the estimation results below to excluding employers with presence in
} 
more comparisons between employers used in our analyses and the rest of Moscow legal entities and discusses the representativeness of our data.

Even though we are thus reasonably confident that the remaining data include for most part legitimate companies and sources of income, in the statistical analyses below we take some extra steps to eliminate potential problems from including car owners with income sources unrelated to legitimate employment. First, we exclude observations on earnings that were below the official minimum wage in any given year (5-7 percent of observations, depending on the year). We also exclude car owners whose reported earnings exceeded the equivalent of $\$ 100,000$ in any given year (less than 0.3 percent of observations) out of concern that the link between earnings and car values may be problematic in such cases. Second, we examined sources of income of car owners in our sample and identified and eliminated individuals whose sole source of income appeared to be not from employment (lottery winnings, interest and dividend payments, insurance payments, research grants, etc.). Third, we excluded individuals younger than 18 and older than 60, which is the retirement age for males in Russia (for females it is even lower at 55). Our sense is that in the vast majority of the remaining cases we are looking at "serious" car owners whose main source of income is legitimate employment (even though possibly with a large fraction of "black wages").

\subsection{Summary Statistics}

The total number of observations on car owners owning cars with valid VINs, excluding the bottom 20 percent (owning cars with the total market value of $\$ 1,200$ or less) and receiving non-zero official earnings in at least one year in our data is 643,408 , but it is reduced to 391,052 once we exclude individuals with incomes coming not from employment, below the minimum wage or above the equivalent of inflation-adjusted $\$ 100,000$ in any given year, and those younger than 18 and older than 60. Of these, 186,768 observations are generated in the private, non-foreign owned firms, 188,679 observations are generated in government employment (including government services, such as law enforcement, education, health care, etc.) and state-owned firms, and 15,605 observations are generated in legitimate foreign-owned companies. For each year, we 
also calculated the percentile of an individual in our sample in the overall earnings distribution of his or her employer (which captures the relative position of the individual in the employer's hierarchy) and the size of the employer by counting the total number of entries pertaining to its identification number. All ruble values were converted to US dollars using average market exchange rates for each year and the dollar values were adjusted to 1999 dollars using the Bureau of Labor Statistics Consumer Price Index.

Table 1 presents basic summary statistics. Several features of the data immediately attract attention. First, looking at car values, employees in foreign-owned firms have on average 5.6 percent more expensive cars than employees in private Russian firms. But comparing the corresponding numbers for reported earnings, those in foreignowned firms exceed those in private Russian firms on average by more than 300 percent. The picture is similar when comparing employees of foreign-owned firms to employees in government agencies and state-owned enterprises, except that both car values and reported earnings are lower in government employment than in the private sector. As a result of this, the simple mean ratio of car values to income is about 75 percent lower in foreign-owned firms compared to other employers. Mean car values are almost double the mean amount of annual earnings among car owners employed in private and government/state-owned sector, which makes them look unrealistically high.

Comparing demographics, car owners in foreign-owned firms are about 4.5 years younger than those in Russian private firms and about 6 years younger than in government employment. Car owners in foreign-owned firms are also more likely to be female. The percentiles in the overall earnings distribution of employers, on the other hand, are very similar and much above the median, indicating, not surprisingly, that car owners are overall more productive workers in their respective employers. Also, the average size of multinationals in Moscow is relatively small, about 40 percent of the average size of private firms and just 8 percent the size of government agencies/stateowned enterprises. The fraction of car owners among multinationals' employees is, on the other hand, twice as high as in government employment and about 40 percent higher than in private Russian firms, indicating (once again not surprisingly) that multinationals on average hire workers of higher productivity and also that earnings may be distributed less unequally in multinational employers than in other employers. More equal 
distribution of incomes in multinationals can also be seen in that the ratio of standard deviation to mean is lower among their car owners than among car owners employed in non-foreign-owned firms sector and the same is true of the corresponding Gini coefficients (not shown).

Significantly, if one were to do labor productivity comparisons between multinationals and private Russian firms on the basis of reported earnings in Table 1, one would inevitably conclude that foreign-owned companies were on average 4.14 times more productive. However, looking at car values, one cannot but help suspecting, even from these most basic summary statistics, that most of this observed differential is actually due to differences in transparency (a high fraction of "black wages" among nonmultinationals). Below we put this conjecture to scrutiny in the regression framework and we also look at how higher transparency of multinationals affects the transparency of their employees before and after they work for multinationals and whether it also spreads to other Russian firms through the channel of labor mobility. We begin by specifying our empirical estimation model in the next subsection.

\subsection{Estimation Model}

Our approach starts from the observation that it is relatively easy to misreport earnings, but it is very costly to drive an unregistered vehicle. ${ }^{11}$ This difference is the key to our identification strategy, which employs matched administrative data on wages and car values to measure hidden earnings. Specifically, we assume that employers pay a certain fraction of true economic earnings of their employees in "black wages," either explicitly (in envelopes) or implicitly (as in cases of employee theft or side jobs using workplace facilities and working time).

Specifically, let employee $i$ 's earnings at time $t$ working in firm $j$ be reported in the amount of $E_{i j t}^{R}=\Gamma_{i j t} E^{*}{ }_{i j t}$, where $E_{i j t}^{*}$ are true economic earnings and $\Gamma_{i j t}$ is the fraction reported. This fraction will likely depend on employer characteristics $\mathbf{S}_{j t}$, such as ownership, sector of activity, firm size, etc. The vector $\mathbf{S}$ will also include indicators for

\footnotetext{
${ }^{11}$ Moscow police routinely conduct traffic stops to check the paperwork. Unregistered vehicles may be impounded and can be recovered only after paying a fine and producing the registration document.
} 
workers hired from foreign-owned companies to capture the effect of labor exchange with multinationals.

The fraction $\Gamma_{i j t}$ may also depend on a range of individual-specific characteristics $\mathbf{X}_{\mathbf{i}}^{(1)}$, such as age, gender, position in the firm's hierarchy and so on. Finally, there might be time effects in reported earnings caused, for example, by institutional changes. Thus, we consider the following specification for reported earnings:

$$
\ln E_{i t}^{R}=\ln E^{*}{ }_{i t}+\mathbf{b}^{\prime} \mathbf{S}_{i t}+\mathbf{g}_{1}^{\prime} \mathbf{X}_{i t}^{(1)}+\varphi_{1}(t)+\eta_{i t},
$$

Coefficients $\mathbf{b}$ are the main focus of our analysis as they measure average income hiding associated with different characteristics of employers $\mathbf{S}$. The more negative the coefficient $\beta_{k}$, the larger the fraction of hidden earnings in total economic earnings among individuals employed in the category of employers possessing characteristic $k$ and vice versa. The identifying assumption is that while the fraction of reported income depends on $\mathbf{S}$, the demand for the stock of cars has the same (controlling for individualspecific characteristics) functional form in all sectors. Specifically, we consider the following car stock demand equation:

$$
\ln C_{i t}=\lambda \ln E_{i t}^{*}+\mathbf{g}_{2}^{\prime} \mathbf{X}_{i t}^{(2)}+\varphi_{2}(t)+u_{i t}
$$

That is, the demand for the stock of cars depends on actual earnings $E^{*}{ }_{i t}$, individual characteristics $\mathbf{X}_{i t}^{(2)}$, time effects $\varphi_{2}(t)$, and an individual and time specific disturbance term $u_{i t}, E\left[u_{i t}\right]=0$.

In order to estimate coefficients $\mathbf{b}$ associated with particular employer characteristics $\mathbf{S}$, we use equation (2) to substitute for unobserved actual economic earnings $E^{*}{ }_{i t}$.

$$
\ln E_{i t}^{R}=\frac{1}{\lambda} \ln C_{i t}+\mathbf{b}^{\prime} \mathbf{S}_{\mathbf{i t}}+\mathbf{g}^{\prime} \mathbf{X}_{\mathbf{i t}}+\varphi(t)+\varepsilon_{i t}
$$

where $\mathbf{g}=\mathbf{g}_{1}-\frac{1}{\lambda} \mathbf{g}_{2}, \varphi(t)=\varphi_{1}(t)-\frac{1}{\lambda} \varphi_{2}(t)$, and $\varepsilon_{i t}=\eta_{i t}-\frac{1}{\lambda} u_{i t}$. Unfortunately, in general estimation of equation (3) is likely to produce biased estimates of $\mathbf{b}$ since car values are correlated with part of the error term. However, if the value of income elasticity of demand $\lambda$ is known, we can estimate the relative (non)transparency of earnings associated with employer characteristics $\mathbf{S}$ by using the following regression equation: 


$$
\ln E_{i t}^{R}-\frac{1}{\lambda} \ln C_{i t}=\mathbf{b}^{\prime} \mathbf{S}_{\mathbf{i t}}+\mathbf{g}^{\prime} \mathbf{X}_{\mathrm{it}}+\varphi(t)+\varepsilon_{i t} .
$$

In the empirical analysis below we employ the value of $\lambda=0.35$ as estimated in BML using a sample of employees of foreign corporations where we have reasons to believe that they reported wages and salaries of their employees truthfully. ${ }^{12}$ Most of the results reported below are robust to reasonable variations in the value of the parameter $\lambda$ (see Section 5.2 and Table 11).

\section{Results}

\subsection{How Much More Transparent Are Multinationals?}

To evaluate exactly how much more transparent foreign corporation are in their labor contracts using our empirical estimation model, Table 2 presents the results of estimating regression (4) in both pooled OLS and individual fixed-effects specifications. We include percentile in the earnings distribution of the employer in both specifications, as well as age and a male dummy in the pooled OLS specification. Both specifications also include observation year dummies (with the omitted year dummy being 1999).

Our main variable of interest is the dummy equal to 1 if the company was foreignowned and 0 otherwise. We also include a dummy equal to 1 if the employer was a government entity or a state-owned enterprise and zero otherwise. Since other employer characteristics such as firm size and sector of economic activity may also affect the fraction of economic earnings paid to employees in the form of "black wages," we include the (log of) the number of employees as well as 17 industry/sector dummies as controls, although to save space we report only a few coefficients on select sector dummies in Table 2 (see Appendix 3 for the details of sectors of economic activity classification and the distribution of those sectors in our sample).

The coefficient on the foreign ownership dummy is estimated to be 1.628 in the pooled OLS specification and 1.080 when controlling for individual fixed effects. The effect has high economic importance: in the OLS specification, other things equal,

\footnotetext{
${ }^{12}$ The value of $\lambda=0.35$ is also very close to estimates obtained from similar NLSY data, where income underreporting is presumably a non-issue. See BML, Appendix 4 and 5 for details.
} 
foreign-owned firms are estimated to report on average more than 4 times $(\exp (1.628)-1$ $=4.094)$ higher earnings paid to their employees with the same car values than private Russian firms. In the fixed-effect specification the effect is smaller at 1.945 times, but still large and statistically very highly significant.

The higher transparency of foreign-owned firms comes as no surprise, of course, as it can be seen in the raw data in Table 1. The regression estimates in Table 2 are also consistent with the BML estimates employing a smaller representative sample of car owners with observations on non-zero earnings and car values in all 5 years. ${ }^{13}$

The effects of firm size and sector of economic activity are also in line with the BML findings. Firm size has a statistically and (at least in the pooled OLS specification) economically highly significant effect on the transparency of reported earnings; laborintensive sectors such as trade and services as well as sectors with a lot of opportunities to hide earnings, such as banking and finance, are relatively less transparent than manufacturing, utilities and IT and communications (which is the omitted sector in Table 2). There is also an overall trend towards more transparency of reporting over time, especially pronounced between 2000-2002, which coincides with the big tax reform that reduced the burden of both personal income tax and the payroll tax (Gorodnichenko et al. [2009]). Finally, age has a positive effect on transparency (presumably because older individuals are closer to retirement age and are thus more concerned about losing employers' contributions to their pension fund, which is only paid out of the "white" part of the wages). An individual's position in the employer's hierarchy (measured by his or her percentile in the earnings distribution of their employer) also has a positive effect on transparency. Since we discussed all these findings in detail in our previous study, we do not repeat this discussion here but we will continue to use firm size, sector of activity and other employer and individual characteristics as controls whenever appropriate.

\subsection{Multinationals' Culture of Transparency and Domestic Firms}

Since reducing the "black" component of wages and salaries and cracking down on employee theft and arbitrary behavior by management are important steps toward

\footnotetext{
${ }^{13}$ The coefficients on foreign ownership dummy in cross-section and fixed-effect estimations in BML were 1.487 and 1.016, respectively, on 15,492 observations.
} 
improving efficiency of economic transactions (to say nothing of government tax revenues), the question whether the culture of higher transparency exhibited by foreign corporations spreads to domestic firms is of first-order importance. In this section, we focus our attention on how economic ties to multinationals affect the transparency of domestic private firms. We also compare them to the effects on "black wages" in government employment. ${ }^{14}$

To obtain a measure of ties to multinationals, we used all the 13,599,649 observations on the 14,000 income-generating employers for which we had assigned ownership (see Section III above) and recorded all moves by income recipients (not necessarily car owners) from foreign-owned firms to non-foreign owned firms and entities in all years covered by our data (1999-2003). Anyone who moved from a foreign-owned firm to a domestic entity once was "labeled" appropriately, and we then computed the ratio of the number of such workers to the total number of observations on individuals employed in any given domestic firm or government entity for each year. This ratio gives us the firm-year specific fraction of workers with observed prior experience of working for foreign-owned firms in the total number of workers in a domestic firm, which we will call "fraction of workers with multinational experience," or "multinational fraction" for short.

Since our data window is limited to five years (1999-2003), the multinational fraction is by construction zero for all domestic firms in 1999. Thus, unless the firm itself was founded in 2000 or later, we cannot meaningfully use the absolute magnitude of this fraction in our econometric analysis. ${ }^{15}$ We can, however, use the change in the

\footnotetext{
${ }^{14}$ A priori, it makes sense to assume that whatever culture of transparency exists in government employment will not likely be affected by individual workers moving from foreign-owned sector. If, contrary to this expectation, we did find a significant effect on government employment, however, that would be a signal that our data may be capturing something other than transparency culture spillovers, so looking at government employment provides a robustness checks for findings in the private sector.

${ }^{15}$ We did try estimating a regression with a dummy indicating whether a domestic company hired somebody from a foreign-owned company or not during the period covered by our data and also using the fraction of such hires in a pooled OLS regression. Neither the dummy nor the fraction (or any function of it) had any effect on transparency. The results of such a regression on subsample of observations on firms for which we know that they were founded after 1999 are presented below.
} 
fraction of workers with experience in foreign-owned firms over time and estimate its effect on the increase in transparency of reported earnings by domestic firms experiencing such an increase, while controlling for employer (and individual) fixed effects. The results of this analysis will be presented in subsection 4.2.2 below. Before that, we look for more direct evidence of corporate culture spilling over to domestic firms from their foreign partners utilizing information on firms' founding background.

\subsubsection{Evidence From Firms' Backgrounds}

As mentioned before, we assigned ownership and sector of economic activity to 14,000 employers. To go beyond these assignments and acquire more details about how the firms were founded (and when), we went to firms' websites and other sources of company histories. As a result of this, we have been able to obtain additional information on 2,226 non-foreign owned Russian firms about the background of their founding. In particular, we learned whether foreign partners were involved from the outset (such as a firm being founded as a joint venture with foreign investors holding a minority share, or an authorized distributor of a branded foreign product, etc.). These 2,226 employers cover about 40 percent of all our data on car owners. We were also able to identify the year the firm was founded for about half of those firms $(1,031)$.

Among the 2,226 employers with known history, foreign partners were involved in founding 105 firms, 99 of which were private (the rest were joint ventures with Moscow city or federal governments), with about 5,000 observations in our sample. For 82 out of 99 private firms founded jointly with foreign partners we were able to determine the year of founding, and in 80 percent of the cases the founding year dates back to the last years of communism or the very first few years of the transition (19881994). It turned out that most of these firms had long outgrown the initial circumstances surrounding their founding - the Russian owners often bought out foreign partners in former joint ventures or former distributors of foreign products long ago started their own production lines. Thus, any difference in the culture of these firms and other firms during the period of our observation can indeed be traced to historical circumstances surrounding their founding. 
In Table 3 we present the results of estimating the regression similar to (4) in four different specifications, with additional variables designed to capture the influence of the firm's founding background on the transparency of wages it pays to its workers. We exclude observations on workers who themselves had work experience in multinationals, so all the results pertain to employees of foreign-related companies who themselves were not observed working in foreign-owned firms at any point in our data.

Specifications (1) and (2) include observations on car owners in private domestic companies for which we know the circumstances of their founding. Of course, firm age and, more generally, the year the company was founded may also affect transparency, so in specification (2) we control for this non-parametrically by including 16 founding year dummies (from 1988 to 2003). This also reduces the sample size as we were not able to identify founding dates for about half of the employers used in this estimation. All specifications include all other controls as in Table 2, although we only show coefficient estimates on selected variables.

As can be seen from the magnitude of the corresponding coefficient in specification (1), being founded in partnership with foreign capital increases the transparency of a Russian domestic company on average by 71 percent. The coefficient estimate is not just large in magnitude but also statistically significant at the 1 percent level. Adding founding year dummies reduces this coefficient just marginally although it is less precisely estimated, but overall the results are very similar. This is the most direct evidence we have that interaction with the corporate culture of multinationals (especially early on) did make Russian companies significantly more transparent than their peers.

We also check how these results hold in a broader part of the data. For this purpose, we continue excluding from the estimation the companies for which we do not have information about how they were founded but where we also observe workers with prior experience of working for multinationals (primarily because we cannot be sure whether some of these companies also had foreign partners at the time they were founded or not). But we include domestic private firms which never hired workers from multinationals during the period covered in our data (assuming that they were highly unlikely to have foreign partners at the time they were founded), and also foreign-owned firms. In specification (3) we simply compare the transparency of income reporting in 
those firms where we do not observe any hires from multinationals with the sample of firms which do such hiring and foreign-owned firms. The coefficient on the dummy capturing a non-zero multinational fraction in a domestic firm workforce is positive but small in magnitude and statistically barely significant.

In specification (4) we add the dummy that captures whether the company was founded in partnership with foreign capital. The coefficient on this dummy is, once again, economically and statistically highly significant. In this larger sample of employers (covering more than 70 percent of observations on all car owners in our sample employed in the Russian private sector and all observations on car owners employed by foreign corporations), being founded in partnership with foreign capital roughly doubles the transparency of wages and salaries. While domestic private firms founded jointly with foreign capital are still way less transparent than foreign-owned firms, we can clearly see their position "in-between" the two cultures.

We also utilized the limited number of observations on firms where we know the date of founding was between 2000 and 2003 to see how the multinational fraction we computed using our data (which in the case reflects the actual such fraction) affects transparency of income reporting for employees in those firms that themselves did not come from multinationals. Table 4 presents estimation results in three different specifications. In specification (1) we include only the dummy equal to one if a firm had a non-zero multinational fraction and zero otherwise (along with all other usual controls). The coefficient on this dummy in the subsample of recently founded firms is positive, large and statistically highly significant. In specification (2) where we control for the years the companies were founded, the coefficient on the dummy for our proxy of ties to foreign sector is almost the same. Finally, in specification (3) we limit the sample to only those firms founded between 2000-2003 which had a non-zero fraction of workers hired from multinationals in all years and look at the effect of the size of this fraction on transparency. The coefficient on the (log of) the fraction of employees that came to private domestic firms from foreign-owned firms is large, even though the robust standard errors (clustered for 71 employers in the sample) are large, so the estimates are not very precise. Overall, the results presented in this section suggest that close ties to foreign capital, including hiring from multinationals at early stages of company 
existence, have a sizable effect on transparency. We now turn to examining these effects by exploiting time variation in the fraction of hires from multinationals.

\subsubsection{Fixed Effects Estimates}

As already mentioned, for companies founded before 2000 (which comprise 99 percent of our data on car owners employed in the Russian private sector) we cannot use the absolute level of the multinational fraction as a proxy for ties to the foreign sector because of the limited time coverage of our data. But if we observe a domestic company hiring relatively more from multinationals over the five years that we have data coverage for (meaning that its multinational fraction, starting from zero in 1999, keeps increasing), that could be a sign of strengthening ties to foreign corporations. Once we control for employer-fixed effects, the starting conditions prior to 1999 cancel out, and we can see if increases in this fraction are associated with spillovers of the culture of transparency from multinationals.

There might also be unobserved individual characteristics, including but not limited to different preferences for transparency that could lead certain types of workers to join or leave companies hiring workers from foreign corporations. To control for this possible selection effect in the most general form, we conduct our estimates controlling for employer $\mathrm{X}$ individual fixed effects in all regressions below. We also limit observations to employees of domestic firms who had no prior working experience in foreign-owned firms in our data and who stayed with the same firm from the previous year (we call them "stayers"). In particular, this automatically excludes all workers who moved from the multinationals in any given year and may have different transparency from their peers because of that (we look at these movers below, in Section V).

Table 5 presents the results of estimating the following equation:

$$
\ln E_{i t}^{R}-\frac{1}{\lambda} \ln C_{i t}=f_{j i}+\alpha F F_{j, t}+\mathbf{b}^{\prime} \mathbf{S}_{\mathrm{it}}+\mathbf{g}^{\prime} \mathbf{X}_{\mathrm{it}}+\varphi(t)+\varepsilon_{i t}
$$

In equation (5) $F F_{j, t}$ is the (log of) multinational fraction. Since the regression includes also the log of total number of employees in the company to control for firm size, the coefficient on $F F_{j, t}$ in the $\log$ specification will be the same as on the $\log$ of the absolute number of workers with prior experience in a foreign-owned firm. We also conducted the estimates using the absolute level of the multinational fraction instead of 
its $\log$ (specifications (2) and (5) in Table 5). As already mentioned, we include employer $\mathrm{X}$ individual fixed effects $f_{j i}$ to control for unobserved individual- and employer-level heterogeneity. ${ }^{16}$ All regressions include also time fixed-effects and timevarying individual-level controls (percentile in the employer earning distribution and, in the first difference specifications (3) and (6), also the dummy for male gender).

Our variable of interest is $F F_{j, t}$, the estimated coefficient on which measures how our proxy for income reporting transparency changes for an average "stayer" in a domestic private company when this company hires more workers from multinationals. Table 5 contains separate estimates for the subsamples of employees of private and stateowned domestic establishments (the latter category includes also government agencies). We also estimated the same regression in first differences.

Estimation results in the first three columns of Table 5 indicate that an increase in the multinational fraction among employees in domestic private firms is associated with more transparent wages for stayers in all specifications. The economic effects are sizeable. For instance, a one standard deviation increase in (log of) the fraction of foreign workers is associated with an increase in transparency by about 15 percent. Notably, we do not find any similar evidence in the government sector (point estimates suggest even negative effects but are not significant).

It is conceivable that the estimated effect of hiring more from multinationals may actually reflect some unobservable time-varying heterogeneity. Obviously, we cannot include employer-time fixed effects in regression (5) because the fraction of hires from multinationals is constant for a given employer in a given year. But we re-estimated regression (5) including also the interaction terms between 17 sectors of economic activity and time fixed effects. This allows us to eliminate unobserved heterogeneity coming from sector-specific shocks causing both hiring more from multinationals and increased transparency to happen concurrently. The results (not shown) were qualitatively the same even after sector-specific time-varying effects were controlled for.

It is also interesting to see how increased hiring from multinationals affects reported incomes and car values separately. Table 6 presents the results of estimating the

\footnotetext{
${ }^{16}$ Many workers in the "stayers" category remained employed in their respective employers throughout the timeframe of the analysis. For them individual fixed effects absorb employer fixed effects.
} 
same regression as in (5) (with $F F_{j, t}$, specified as $\log$ multinational fraction) but with the dependent variables being (log of) reported income and (log of) market values of cars separately. Since especially the adjustment in car values is likely to take time to materialize, we show both the contemporaneous impact and the impact on reported earnings and car values in the following year. ${ }^{17}$

In the private domestic sector both contemporaneous and future reported incomes of stayers tend to increase as the firm hires more workers from foreign companies. ${ }^{18}$ But we do not see any effect (point estimates are even slightly negative) on car values, which provides support to the interpretation that the effect of hiring from multinationals primarily works through increased transparency, at least in the short run. Once again, the effects on both reported incomes and car values in government employment are indistinguishable from zero.

To sum up, fixed-effect estimates confirm the presence of an economically significant association between increasing ties to multinationals and wage transparency of stayers in private domestic companies. In the next section we discuss some possible mechanisms for these "transparency spillovers."

\section{Some Possible Mechanisms For Spillover Transmission}

\subsection{Movers Between Multinationals and Domestic Firms}

In this section, we first take a close look at workers who move between multinationals and private domestic firms. A priori, there are reasons to expect these movers to be a select group of individuals as compared to workers who are continuously employed in either the foreign-owned or the domestic private sector. For example, a worker may at least partly acquire the culture of transparency through experience working for a multinational. As several studies in similar contexts have shown (see, e.g., Bloom et al. [2011]), some of the "bad" practices in developing countries seem to persist, at least to a certain degree, simply because people cannot imagine how things can be

\footnotetext{
${ }^{17}$ Unfortunately, we could not estimate the impact beyond the second year because the sample size becomes too small.

${ }^{18}$ The effect on future incomes is measured imprecisely because of a much smaller sample size but it is positive and similar in magnitude to the effect on contemporaneous incomes.
} 
done otherwise; once they are shown how it can be realistically done, many are willing to embrace the alternative. Joining a Russian firm after a stint with a foreign-owned firm may also make the worker worry about the appearance of a sudden, unexplained drop in the official wage, which may draw extra scrutiny from the authorities. ${ }^{19}$ In either case we would expect to observe a higher propensity to enter into relatively more transparent labor contracts by workers who move from multinationals to domestic firms compared to workers of similar productivity who have never worked for multinationals.

On the other hand, workers who quit multinationals and are re-employed by private Russian firms may simply be misfits in their previous foreign-owned employers. For instance, they may be less productive or they may try to engage in some practices (such as theft or moonlighting during work hours) that are tolerated in Russian firms but not in multinationals. In cases like this we would expect movers from multinationals not to be so different in terms of transparency from their peers in Russian private firms, but we would expect to see them either be less productive or less transparent (or both) when compared with their peers who stay employed in multinationals.

Table 7 presents some raw evidence using observations on before- and after the move reported wages, market car values and percentiles in the employer's earnings distribution (EED) of car owners who moved from foreign-owned to domestic firms (in the first row) and vice versa (the last row). The other rows compare them to other categories of car owners - stayers with the same employer in a domestic private firm (second row in Table 7), workers who also changed employers from year $t-1$ to $t$ but within the domestic private sector (third row), car owners who stayed with the same employer in the foreign-owned sector (fourth row) and car owners who changed employers within the foreign-owned sector (fifth row).

The data are highly suggestive. Looking at car owners who moved from foreignowned to domestic private companies in the first row, we see that their reported earnings decline by 46 percent, but their car values actually increase by 2.4 percent. Moving from a domestic to a foreign-owned company, on the other hand, results in an 82-percent increase in reported earnings but car values actually even slightly decline!

\footnotetext{
${ }^{19}$ Websites mentioned in an earlier footnote discuss how authorities may use sudden big fluctuations in reported earnings to crack down on "black wages."
} 
As a result, the ratio of car values to reported earnings among individuals who move from multinationals to domestic firms almost doubles and becomes statistically indistinguishable from the corresponding ratio among stayers in domestic companies. For 44 individuals for whom we had another observation in their new domestic employer, we also checked what happens to reported earnings and car values in the next year after the move. The results (not shown) indicate that in the next year, earnings of former multinational employees go up by 34 percent but their car values increase by the same magnitude, so that the ratio of mean car values to reported earnings is unchanged. Note also that the percentile in EED with the new domestic employer is higher than the percentile in EED with the previous (foreign-owned) employer (and it is even higher in the next year after the move for those for whom we have the third observation). Overall, it does not look like movers from multinationals to domestic firms lose much in actual wages, despite strong evidence to the contrary in reported wages.

It is also instructive to compare these movers with workers who stay in the foreign- sector, either with the same employer (row 4 in Table 7) or changing employers (row 5 in Table 7). There is no difference in terms of car values either at $t-1$ or at $t$ between stayers in foreign-owned firms and movers to domestic private firms, but the movers' reported earnings are on average just 53 percent of the stayers at $t$ - 1 , when both are still employed in the foreign sector. In year $t$, when the movers are already employed by domestic firms, their reported earnings are just 27 percent of those who stayed in the foreign sector, and the average ratio of car values to incomes is 4 times higher.

The evidence in Table 7 does not square well with the idea that an average individual moving from a multinational to a domestic firm is implanted with the culture of transparency that he carries with him. If anything, the emerging picture seems to be consistent with the interpretation that the movers quit the foreign sector (or are fired by their employers) because they do not embrace this culture. This does not, however, immediately imply that none of them can still serve as "transmitters" of the culture of transparency from multinationals to domestic firms.

To probe this issue more deeply we conduct regression analysis. Specifically, we estimate the following equation 


$$
\ln E_{i t}^{R}-\frac{1}{\lambda} \ln C_{i t}=\alpha+\beta M F_{i t}+\mathbf{b}^{\prime} \mathbf{S}_{\mathbf{i t}}+\mathbf{g}^{\prime} \mathbf{X}_{\mathrm{it}}+\varphi(t)+\varepsilon_{i t},
$$

where the left-hand side is our measure of transparency of income reporting as in (4), and $\mathbf{S}, \mathbf{X}$, and $\varphi(t)$ are, once again, vectors of controls for employer characteristics (sector of economic activity and log number of employees), individual characteristics (age, gender, percentile in EED) and year dummies representing the time trend, respectively. The variable of interest is $M F_{i t}$, which is the dummy equal to 1 if the individual was employed by a foreign-owned company in year $t-1$ and by a domestic private company in year $t$. The regression is estimated on the same sample of individuals satisfying our usual criteria for both years $t-1$ and $t$ (that is, in both years we exclude the bottom 20 percent of car values, car owners with incomes not from employment, below the minimum wage and above the equivalent of $\$ 100,000$, younger than 18 and older than 60$){ }^{20}$ The coefficient on the variable of $M F_{i t}$ is thus designed to capture the difference in transparency (if any) between movers from multinationals and stayers in domestic private companies.

Table 8 presents the results of estimating equation (6) on four different samples of domestic private firms. In column (1) we use all available observations. The results confirm the findings in the raw data - the transparency of the movers from foreign-owned firms is statistically and economically indistinguishable from that of "stayers."

In column (2) we limit the sample to employers with the overall multinational fraction above the $90^{\text {th }}$ percentile (corresponding to this fraction being greater or equal than 0.0104). The coefficient on the dummy for being employed by a multinational in the previous year is statistically not significant but it is now positive and of relatively high magnitude. In column (3) we further narrow down the sample to employers with the multinational fraction above the $99^{\text {th }}$ percentile (greater or equal than 0.0465). Since we are left with just 370 observations, the coefficient on the dummy for being employed by a multinational in the previous year is estimated very imprecisely, but it is even much larger in magnitude and statistically significant at the 10 percent level. Finally, column (4) uses the sample limited to private firms founded in partnership with foreign capital as explained in Section 3.2.1 above. Once again, the number of observations is limited and

\footnotetext{
${ }^{20}$ In addition, we limit the sample to car owners who either moved from a foreign-owned firm to a domestic private employer in year $t$ or have stayed with the same domestic private employer in both years.
} 
the coefficient is estimated imprecisely but it appears to be even larger in magnitude than the previous one.

To sum up, there is little evidence of higher intrinsic (or acquired) culture of transparency among all workers who move from multinationals to domestic private firms compared to workers with no experience in multinationals. But we do find some evidence to this effect in select samples of employers with close ties to multinationals. We next examine in more detail the channels through which hiring workers from multinationals may affect the transparency of "stayers" in domestic private firms.

\subsection{Searching for the Mechanism: Vertical or Horizontal Transmission?}

In section 4.2 we found that an increase in the inflow of employees with experience in foreign-owned companies is associated with increased transparency of "stayers," i.e., employees who themselves continue to be employed by their current domestic private employer and had never worked at a foreign company within the timeframe of our analysis. In this section we consider two channels through which hiring of workers from multinationals might increase the transparency of such "stayers."

One such channel is where a high-ranking employee coming from a foreign corporation initiates changes in operations of the domestic firm to bring it closer to the corporate standards of his previous (foreign-owned) employer. In particular, this could involve restructuring the contracts of incumbent workers towards lower share of "black wages." Of course, the ability of a foreign newcomer to make such changes would crucially depend on his position in the chain of command. Hence, under this story we would expect that changes in transparency will be the largest when individuals from multinationals are hired for top managerial positions: that is, hiring a CFO should have different effects than hiring a janitor. We say that in this case, the culture of transparency spills over vertically from the top to the bottom of the firm's hierarchy.

Another possible channel is where the domestic firm engages in "benchmarking" of the following kind. We found some partial evidence in the previous section that workers moving from foreign-owned companies tend to negotiate relatively more transparent contracts. We can also see from Table 7 that the absolute level of wages and salaries reported by domestic private companies for recent movers from multinationals is 
much higher than the corresponding level of wages and salaries reported for other movers (not from multinationals), and it is also somewhat higher than those of the stayers (especially considering that stayers are located higher in the earnings distribution of their employers).

These higher incomes of movers from foreign-owned firms might translate into better income reporting for incumbent employees in similar jobs, since paying dramatically different "white wages" in such cases may cause disruption in the workplace. In this case, we say that transparency spills over horizontally, with "stayers" closer in the job responsibility space to a newcomer from a foreign entity experiencing larger increases in transparency.

To probe empirically for the presence of vertical spillovers we utilize two measures. First, for each company in each year we compute the maximum percentile in the wage distribution occupied by a person with prior working experience in a foreignowned company. Second, for each "stayer" in a domestic company we create a dummy indicating whether there is a person with prior experience in a foreign-owned firm above him/her in terms of the employer earnings distribution.

To look for the presence of horizontal spillovers, for each "stayer" in a domestic company we calculate his distance from the closest person who came from a foreignowned firm. We utilized three measures of such distance. First, we compute the minimum distance in the current employer wage percentiles between wages received by a given "stayer" and movers from foreign-owned companies. It is possible, however, that earnings of employees who have just moved from foreign-owned companies might not reflect their true position in the firms' hierarchy due to differences in income reporting. To address this possible problem, we also compute the minimum distance as above, using previous (foreign-owned) employer percentiles for movers. ${ }^{21}$

The third measure we use is based on percentiles in terms of car values. Inasmuch as car values are a good proxy for true earnings, this is likely to be the most adequate measure, independent of any misrepresentation of reported wages that may be going on. The drawback of this measure is that by construction it is defined over a much

\footnotetext{
${ }^{21}$ Just like we did when computing the multinational fraction, we compute all of the above-mentioned measures utilizing the available data on all workers, not just car owners.
} 
smaller subsample of car owners. Still, given the widespread presence and heterogeneity of "black wages," this distance is our preferred measure of how similar actually the mover from a multinational is to his or her new colleagues in the Russian firm.

We regress our measure of the transparency of reported earnings (the elasticityadjusted income car gap) for the sample of "stayers," with the above five measures of distance from their new colleagues coming from multinationals as our variables of interest. As before, to account for individual and firm level unobserved heterogeneity we include employer X individual fixed effects:

$$
\ln E_{i t}^{R}-\frac{1}{\lambda} \ln C_{i t}=f_{i, j(i)}+\beta P D_{i, j(i) t}+\mathbf{g} \mathbf{X}_{\mathbf{i t}}+\varphi(t)+\varepsilon_{i, j(i) t}
$$

Here $P D$ measures intensity of vertical/horizontal spillover as described above, while $f_{j(i)}$ corresponds to employer $\mathrm{X}$ individual fixed effects.

Table 9 presents the results of estimating regression (7) for employees of private domestic companies using all five of the above measures. Measures of vertical spillover have the expected (positive) sign but are not statistically significant and implied effects are small. ${ }^{22}$ Measures of horizontal spillovers have the expected (negative) sign and especially the coefficient on our preferred measure, the percentile distance in market values of cars, is large in magnitude and statistically significant at the 5 percent level despite the smaller sample size. It thus seems that "stayers" in domestic companies do tend to experience a larger gain in transparency if they are located closer to a mover from a foreign-owned company in the job quality space.

The effects of percentile distances we find in the regressions above might simply reflect an increase in the overall fraction of employees with prior experience in foreignowned companies. Indeed, as a company hires more employees from multinationals, the chances to find a mover from a foreign company nearby increase by construction for each individual "stayer". To control for this, we re-estimated regression (7) including also the ( $\log$ of) fraction of employees with prior experience in multinationals as in Section 4.2. Table 10 presents estimation results. The impact of horizontal spillovers as measured by percentile distance in car values is still significant and of the same magnitude. The

\footnotetext{
${ }^{22}$ E.g., an increase in top wage percentile occupied by foreign worker by 10 percentage points is associated with 4 percent higher earnings, with coefficient being not statistically significant.
} 
magnitude of the corresponding coefficient implies that a decrease in car value distance by 10 percentage points for a given "stayer" as a new employee is hired from a foreignowned firm is associated with an increase in transparency of income reporting also by about 10 percent. Overall, the data provide some support in favor of horizontal spillovers in private domestic companies, especially around true earnings (proxied by car values) but vertical spillovers seem to be of less importance.

\subsection{Robustness Checks}

Our regressions assumed an income elasticity of demand for cars of 0.35 . In Table 11 we reproduce our main regressions from Table 5 using elasticities of 0.25 and 0.45 , both being more than a standard deviation below and above the benchmark estimate of 0.35 . The estimated coefficients are close to the benchmark specification. A higher share of workers from foreign companies leads to higher transparency of earnings in domestic private companies but no effects are observed for state-owned establishments.

We also restricted the sample to employers who are present in all five years in the sample to get rid of dying or newly found firms to see whether that affects our results. The basic patterns remain the same, as shown in Table 12.

We also implemented a variety of additional robustness checks. Since there could be gender differences in the demand for cars as well as in preferences for transparency, we re-estimated all regressions only on the sample of men and got very similar results. We also looked at only workers above the median in the wage distribution of their employers to restrict attention to those above a certain level of productivity. We also experimented with various car value cutoffs, such as a lower cutoff of $\$ 1,000$, or a higher cutoff where we dropped the bottom 30 percent of all car values (those below, roughly $\$ 1,800$ ). In all cases the results were similar. Details are available upon request.

\section{Conclusions}

We have examined the difference in corporate culture between multinationals and domestic private firms in the transitional economy of Russia. Using administrative records on official wages and salaries matched to car ownership data we found that in 1999-2003 foreign-owned firms reported on average four times higher earnings of their 
employees than did domestic private firms for the same car values and other characteristics. Thus, there is strong support in the data for the widespread perception that Russian firms hide a lion's share of actual employee compensation. ${ }^{23}$ One implication of this finding is that estimates that show foreign-owned firms to have much higher labor productivity than their domestic counterparts may be overstating the actual efficiency gap by not taking proper account of hidden earnings (and also hidden sales and profits) in Russian firms.

Another implication, on which we have focused in this paper, is that there is a potential for foreign firms to affect positively the culture of domestic firms. We argued that this could be an important channel through which foreign direct investment may contribute to improved efficiency of the recipient economy because the system of unofficial worker compensation (either through "black wages" or through implicit acceptance of employee theft) is still highly inefficient. In particular, it clearly involves high transaction costs, it puts unnecessary barriers on labor (and general resource) reallocation due to inherent trust problems, it deprives governments of tax revenues and workers of the employer contributions to the retirement fund, etc.

Multinationals comprise a very small part of the economy of Moscow, so it is not surprising that even though some of them had been operating in Russia for about a decade by the time our data coverage starts, their overall influence on the culture of transparency was still negligible in the aggregate data. We did find, however, that private Russian firms founded in partnership with foreign capital were twice as transparent in reporting earnings of their employees as other private Russian companies, even though most of them were currently entirely owned by Russian capital.

We also found rather strong evidence of a positive effect on transparency of increased hiring from multinationals. An increase in the fraction of workers hired from foreign corporations by one standard deviation was associated with 20 percent increase in the transparency of reported incomes for workers who themselves did not come from multinationals, controlling for employer $\mathrm{X}$ individual fixed-effects.

\footnotetext{
${ }^{23}$ Some foreign-owned firms may also not be fully transparent. In particular, the evidence on the relationship between car values and reported earnings of individuals moving between foreign-owned and domestic firms (see Table 7) can perhaps be interpreted in this way.
} 
Of course, we cannot rule out the possibility that there were some other timevarying effects that caused both the fraction of hires from multinationals and the degree of transparency to increase concurrently in affected firms, so we cannot claim to have found a causal relationship between the increase in the fraction of workers hired from foreign-owned firms and increased transparency of domestic firms. But we found that including controls for time-varying sector of economic activity effects does not change the results. We also looked for evidence that transparency of Russian firms may be increasing disproportionately if they hired top executives from multinationals (which could under some circumstances be interpreted as evidence of a deliberate decision taken at some point in time to increase transparency by hiring from multinationals) but we did not find such evidence in our data.

Instead, we found some evidence that a possible mechanism for spillovers of corporate culture from multinationals to domestic firms may involve "horizontal spillovers," that is, spillovers in which domestic private firms adjust officially paid wages and salaries to incumbent workers who are positioned similarly to new hires from multinationals in terms of their job responsibilities. While the evidence is somewhat tentative, there is support for the notion that domestic firms that find it important to hire workers from multinationals for reasons not necessarily related to transparency (such as perhaps their skills), may as a by-product be "pushed" into becoming more transparent.

Culture in general and corporate culture in particular is stubborn and hard to change. There is no better evidence of this than the struggles of the Russian economy and other economies of the former Soviet Union over the 20 years that have elapsed since those countries bid farewell to their "socialist" system. But we also know that eventually cultural changes do come about in response to economic incentives. Foreign capital and especially foreign direct investment may thus play an important role in diffusing not just better technologies and management practices but also the culture of transparent, armslength transactions in recipient countries suffering from inefficient, non-transparent, and insider-oriented culture of doing business. Our paper has shown that there is indeed some evidence of such diffusion taking place, offering a glimmer of hope for the Russian economy. 


\section{References}

Aitken, Brian J. and Ann E. Harrison, 1999. "Do Domestic Firms Benefit from Direct Foreign Investment? Evidence from Venezuela". American Economic Review, Vol. 89, pp. 605-618.

Aitken, Brian, Ann Harrison and Robert E. Lipsey, 1996. "Wages and foreign ownership: a comparative study of Mexico, Venezuela, and the United States", Journal of International Economics, Vol. 40, pp. 345-371.

Alexeev, Michael, and William Pyle, 2003. "A Note on Measuring the Unofficial Economy in the Former Soviet Republics," Economics of Transition, 11 (1), 153-175.

Balsvik, Ragnhild, 2011. "Is Labor Mobility a Channel for Spillovers from Multinationals? Evidence from Norwegian Manufacturing," The Review of Economics and Statistics, February 2011, 93(1): 285-297

Bertrand, Marianne, and Antoinette Schoar, 2003. "Managing With Style; The Effect Of Managers On Firm Policies,” Quarterly Journal of Economics, 68 (4), 1169-1207.

Bloom, Nicholas, Aprajit Mahajan, David McKenzie, and John Roberts, 2010. "Why Do Firms in Developing Countries Have Low Productivity?" American Economic Review: Papers and Proceedings, 100 (2), 619-623.

Bloom, Nicholas, Benn Eifert, Aprajit Mahajan, David McKenzie, and John Roberts, 2011. "Does Management Matter? Evidence From India," Working Paper, Stanford University.

Braguinsky, Serguey, Sergey Mityakov, and Andrey Liscovich, 2010. "Direct Estimation of Hidden Earnings: Evidence from Administrative Data." SSRN Working Paper, available on http://papers.ssrn.com/sol3/papers.cfm?abstract_id=1680968.

Braguinsky Serguey, 2009. "The Rise and Fall of Russian Oligarchs: Quantitative Analysis," Journal of Law and Economics, 52 (2), 307-350.

Braguinsky, Serguey, and Roger Myerson, 2007. "Capital and Growth With Oligarchic Property Rights,” Review of Economic Dynamics, 10 (4), 676-704.

Braguinsky, Serguey, 1999. "Enforcement of Property Rights during the Russian Transition: Problems and Some Approaches to a New Liberal Solution," Journal of Legal Studies, 28 (2), 515-544.

Braguinsky, Serguey and Grigory Yavlinsky, 2000. Incentives and Institutions. The Transition to a Market Economy in Russia, Princeton University Press, Princeton, New Jersey.

Branstetter, Lee, 2006. "Is Foreign Direct Investment a Channel of Knowledge Spillovers: Evidence from Japan's FDI in the United States," Journal of International Economics, 68, 325-344. 
DeBacker, Jason, Bradley T. Heim, ad Anh Tran, 2011. "Importing Corruption Culture from Overseas: Evidence From Corporate Tax Evasion in the United States," Working Paper.

Djankov, Simeon, Ira Lieberman, Joyita Mukherjee, and Tatiana Nenova, 2003. "Going Informal: Benefits and Costs," Chapter 3 in Belev, Boyan, The Informal Economy in the EU Accession Countries: Size, Scope, Trends, and Challenges to the Process of EU Enlargement, Sofia, Center for the Study of Democracy.

Görg, Holger, and David Greenaway, "Much Ado about Nothing? Do Domestic Firms Really Benefit from Foreign Direct Investment?" World Bank Research Observer 19 (2004), 171-197.

Görg, Holger and Eric Strobl (2002a), "Spillovers from foreign firms through worker mobility: An empirical investigation" GEP Research Paper 02/13, University of Nottingham (published as Görg, Holger, and Eric Strobl, "Spillovers from Foreign Firms through Worker Mobility: An Empirical Investigation," Scandinavian Journal of Economics 107 (2005), 693-709.)

Gorodnichenko, Yuri, Jorge Martinez-Vazquez, and Klara Sabirianova, 2009. "Myth and Reality of Flat Tax Reform: Micro Estimates of Tax Evasion Response and Welfare Effects in Russia," Journal of Political Economy, 117 (3), 504-554.

Guriev, Sergei and Andrey Rachinsky, 2006. "The Evolution of Personal Wealth in the Former Soviet Union and Central and Eastern Europe." Working Papers RP2006/120, World Institute for Development Economic Research (UNU-WIDER). Published in Davies, James, ed. Personal Wealth from a Global Perspective, Oxford University Press: 2008

Haddad, Mona and Harrison, Ann, 1993. "Are there Positive Spillovers from Direct Foreign Investment? Evidence from Panel Data for Morocco". Journal of Development Economics, Vol. 42, pp. 51-74.

Hanlon, Michelle, Lillian Mills, and Joel Slemrod, 2007. “An Empirical Examination of Corporate Tax Noncompliance," in Taxing Corporate Income in the $21^{\text {st }}$ Century, eds. Alan Auerbach, James R. Hines, and Joel Slemrod, Cambridge University Press, New York.

Ivanova, Anna, Michael Keen, and Alexander Klemm, 2005. "The Russian 'flat tax' reform." Economic Policy, Vol. 20 (43), pages 397-444.

Johnson, Simon, Daniel Kaufmann, John McMillan, and Christopher Woodruff, 2000. "Why Do Firms Hide? Bribes and Unofficial Activity After Communism," Journal of Public Economics, 76, 495-520.

Kaufmann, Daniel, and Aleksander Kaliberda, 1996. "Integrating the Unofficial Economy into the Dynamics of Post-Socialist Economies: A Framework of Analysis and Evidence," World Bank Policy Research Working Paper, 1691 
Keller, Wolfgang and Stephen Yeaple, 2009. "Multinational Enterprises, International Trade, and Productivity Growth: Firm-Level Evidence From the United States," Review of Economics and Statistics, 91 (4), 821-831.

Lipsey, Robert E. 1994. Foreign-owned firms and U.S. wages. NBER Working Paper no. 4927. Cambridge, Mass.: National Bureau of Economic Research, November.

Lyssiotou, Panayiota, Panos Pashardes, and Thanasis Stengos, 2004. "Estimates of the Black Economy Based on Consumer Demand Approaches," Economic Journal, 114 (July), 622-640.

Pissarides, Christopher A., and Guglielmo Weber, 1989. "An expenditure-based estimate of Britain's black economy,” Journal of Public Economics, 39 (1), 17-32.

Sabirianova, Klara, Jan Svejnar, and Katherine Terrell, 2005. "Foreign Investment, Corporate Ownership, and Development: Are Firms in Emerging Markets Catching Up to the World Standard?" IZA Discussion Paper, No. 1457.

Schneider, Freidrich, and Dominik Enste, 2000. "Shadow Economies: Size, Causes, and Consequences," Journal of Economic Literature, 38 (1), 77-114.

Shleifer, Andrei, and Robert W. Visnhy, 1998. The Grabbing Hand. Government Pathologies and Their Cures. Harvard University Press, Cambridge, Massachusetts.

Shleifer, Andrei, and Robert W. Visnhy, 1997. "A Survey of Corporate Governance," Journal of Finance, 52 (2), 737-783.

Shleifer, Andrei, and Robert W. Visnhy, 1993. "Corruption," Quarterly Journal of Economics, 108 (3), 599-617.

Schneider, Freidrich, and Dominik Enste, 2000. "Shadow Economies: Size, Causes, and Consequences," Journal of Economic Literature, 38 (1), 77-114.

Smarzynska-Javorcik, Beata, "Does Foreign Direct Investment Increase the Productivity of Domestic Firms? In Search of Spillovers through Backward Linkages," American Economic Review 94 (2004), 605-627.

Tanzi, Vittorio, 1983. "The underground economy in the United States: annual estimates 1930-1980,” IMF Staff Papers, 30, 283-305

Vaksberg, Arkady, 1992. The Soviet Mafia. A Shocking Exposé of Organized Crime in the USSR, St. Martin's Press, New York.

Yakovlev, Andrei, 2001. “'Black Cash' Tax Evasion in Russia: Its Forms, Incentives and Consequences at Firm Level,” Europe-Asia Studies, 53 (1), 33-55. 


\section{Tables}

Table 1. Summary statistics

\begin{tabular}{|c|c|c|c|}
\hline & $\begin{array}{l}\text { Private, not } \\
\text { foreign owned }\end{array}$ & $\begin{array}{l}\text { Government } \\
\text { and SOE }\end{array}$ & $\begin{array}{l}\text { Foreign- } \\
\text { owned }\end{array}$ \\
\hline \multirow{3}{*}{ Car Values (C) } & $7,285.49$ & $6,287.99$ & $7,696.57$ \\
\hline & $(11,995.99)$ & $(9,604.65)$ & $(10,028.93)$ \\
\hline & $3,740.15$ & $3,058.97$ & $15,480.11$ \\
\hline Incomes (I) & $(6,928.51)$ & $(4,537.65)$ & $(15,801.55)$ \\
\hline \multirow[t]{2}{*}{ Means ratio $(\mathrm{C}) /(\mathrm{I})$} & 1.95 & 2.06 & 0.50 \\
\hline & 39.70 & 41.47 & 35.27 \\
\hline \multirow[t]{2}{*}{ Age } & $(9.82)$ & $(9.98)$ & $(8.91)$ \\
\hline & 0.78 & 0.71 & 0.67 \\
\hline Fraction Male & $(0.42)$ & $(0.45)$ & $(0.47)$ \\
\hline Percentile in employer & 0.71 & 0.66 & 0.67 \\
\hline earning distribution & $(0.24)$ & $(0.26)$ & $(0.25)$ \\
\hline Employer size (number & 1,754 & 8,811 & 693 \\
\hline of employees) & $(4,287)$ & $(14,886)$ & $(1,255)$ \\
\hline Fraction of car owners & 0.14 & 0.10 & 0.20 \\
\hline in the data & $(0.11)$ & $(0.06)$ & $(0.12)$ \\
\hline Number of observations & 186,768 & 188,679 & 15,605 \\
\hline
\end{tabular}

Source: Authors' estimates using Moscow income and car registry databases for 1999-2003. Excluding car owners with market values of cars in the bottom 20 percent, with incomes not from employment, incomes below the minimum wage and above the equivalent of $\$ 100,000$ in any given year, younger than 18 and older than 60. All values in 1999 US dollars using market exchange rates between the US dollar and the ruble and adjusted for inflation using the US Consumer Price Index. 
Table 2. Estimates of regression (4)

\begin{tabular}{|c|c|c|}
\hline & Pooled OLS & Individual fixed-effects \\
\hline \multicolumn{3}{|c|}{ Ownership: Private domestic is the omitted category } \\
\hline Foreign ownership & $\begin{array}{c}1.628 * * * \\
(0.030)\end{array}$ & $\begin{array}{c}1.080^{* * * *} \\
(0.053)\end{array}$ \\
\hline State ownership & $\begin{array}{c}0.255^{* * *} \\
(0.017)\end{array}$ & $\begin{array}{l}0.268 * * * \\
(0.029)\end{array}$ \\
\hline Log number employees & $\begin{array}{c}0.184 * * * \\
(0.004)\end{array}$ & $\begin{array}{c}0.016 * * * \\
(0.005)\end{array}$ \\
\hline \multicolumn{3}{|c|}{ Select sectors of economic activity (omitted sector, IT and communications): } \\
\hline Banking and finance & $\begin{array}{c}-0.591 * * * \\
(0.035)\end{array}$ & $\begin{array}{c}-0.476^{* * * *} \\
(0.056)\end{array}$ \\
\hline Utilities & $\begin{array}{c}0.021 \\
-0.038\end{array}$ & $\begin{array}{c}0.616 * * * \\
(0.090)\end{array}$ \\
\hline Wholesale and retail trade & $\begin{array}{c}-0.647 * * * \\
(0.033)\end{array}$ & $\begin{array}{c}-0.307 * * * \\
(0.051)\end{array}$ \\
\hline Manufacturing & $\begin{array}{c}0.020 \\
(0.030)\end{array}$ & $\begin{array}{l}0.270 * * * \\
(0.050)\end{array}$ \\
\hline Services & $\begin{array}{l}-0.395^{* * *} \\
(0.034)\end{array}$ & $\begin{array}{c}-0.113 * * \\
(0.051)\end{array}$ \\
\hline Age & $\begin{array}{c}0.020 * * * \\
(0.001)\end{array}$ & \\
\hline Male dummy & $\begin{array}{l}0.092 * * * \\
(0.014)\end{array}$ & \\
\hline $\begin{array}{l}\text { Percentile in employer earnings } \\
\text { distribution }\end{array}$ & $\begin{array}{c}2.372 * * * \\
(0.021)\end{array}$ & $\begin{array}{c}2.591 * * * \\
(0.019)\end{array}$ \\
\hline \multicolumn{3}{|c|}{ Year dummies: omitted year 1999} \\
\hline 2000 & $\begin{array}{c}0.131 * * * \\
(0.009)\end{array}$ & $\begin{array}{c}0.370 * * * \\
(0.008)\end{array}$ \\
\hline 2001 & $\begin{array}{c}0.482 * * * \\
(0.011)\end{array}$ & $\begin{array}{c}0.897 * * * \\
(0.008)\end{array}$ \\
\hline 2002 & $\begin{array}{l}0.622 * * * \\
(0.012)\end{array}$ & $\begin{array}{c}1.220 * * * \\
(0.009)\end{array}$ \\
\hline 2003 & $\begin{array}{c}0.483 * * * \\
(0.012)\end{array}$ & $\begin{array}{c}1.300 * * * \\
(0.009)\end{array}$ \\
\hline Constant & $\begin{array}{c}-20.538^{* * *} \\
(0.042)\end{array}$ & $\begin{array}{c}-19.354 * * * \\
(0.052)\end{array}$ \\
\hline \# of obs. (individuals) & $390,644(203,535)$ & $390,849(203,652)$ \\
\hline Adjusted R-squared & 0.079 & 0.796 \\
\hline
\end{tabular}

Notes: The dependent variable is the "income-car gap", defined as the difference between Log of inflation-adjusted reported earnings and inflation and income elasticity-adjusted Log of car values: $\log E^{R}-1 / \lambda \log C$. Pooled OLS with robust clustered standard errors in parentheses. ***, $* *$, and $*$ indicate significance at 1 percent, 5 percent and 10 percent levels, respectively. Excluding car owners with market values of cars in the bottom 20 percent, with incomes not from employment, incomes below the minimum wage and above the equivalent of $\$ 100,000$ in any given year, younger than 18 and older than $60 .$. 
Table 3. Transparency and founding background

\begin{tabular}{|c|c|c|c|c|}
\hline & $(1)$ & $(2) \mathrm{I}$ & (3) & $(4)$ \\
\hline Foreign partner at founding dummy & $\begin{array}{l}0.538 * * * \\
(0.184)\end{array}$ & $\begin{array}{c}0.514 * * \\
(0.221)\end{array}$ & & $\begin{array}{l}0.721 * * * \\
(0.195)\end{array}$ \\
\hline Log number of employees & $\begin{array}{c}0.177 * * * \\
(0.037)\end{array}$ & $\begin{array}{c}0.174 * * * \\
(0.050)\end{array}$ & $\begin{array}{l}0.261 * * * \\
(0.020)\end{array}$ & $\begin{array}{c}0.262 * * * \\
(0.020)\end{array}$ \\
\hline $\begin{array}{l}\text { Dummy for a non-zero fraction of workers } \\
\text { with prior multinational experience }\end{array}$ & & & $\begin{array}{l}0.117^{*} \\
(0.070)\end{array}$ & $\begin{array}{c}0.091 \\
(0.072)\end{array}$ \\
\hline Dummy for foreign-owned firms & & & $\begin{array}{c}1.726 * * * \\
(0.085)\end{array}$ & $\begin{array}{c}1.740 * * * \\
(0.086)\end{array}$ \\
\hline Constant & $\begin{array}{c}-19.362 * * * \\
(0.438) \\
\end{array}$ & $\begin{array}{c}-18.957 * * * \\
(0.654)\end{array}$ & $\begin{array}{c}-20.164 * * * \\
(0.235)\end{array}$ & $\begin{array}{c}-20.222 * * * \\
(0.237)\end{array}$ \\
\hline Other controls & Yes & Yes & Yes & Yes \\
\hline Founding year dummies & No & Yes & No & No \\
\hline \# of observations (employers) & $60,909(1,201)$ & $27,350(681)$ & $146,094(8,297)$ & $146,094(8,297)$ \\
\hline Adjusted R-squared & 0.122 & 0.111 & 0.133 & 0.134 \\
\hline
\end{tabular}

Notes: The dependent variable is the income-car gap as defined in Table 2. Pooled OLS with robust standard errors clustered by employers in parentheses. $* * *, * *$, and $*$ indicate significance at 1 percent, 5 percent and 10 percent levels, respectively. Excluding car owners with market values of cars in the bottom 20 percent, with incomes not from employment, incomes below the minimum wage and above the equivalent of $\$ 100,000$ in any given year, younger than 18 and older than 60. Other controls in all specifications include 17 dummies for sectors of economic activity, time fixed effects, age, age squared, gender, and percentile in the employer's earning distribution. Specifications I and II include only private domestic companies with known founding background. Specification II includes 16 dummies for years the company was founded (between 1988 and 2003). Specifications III and IV include also observations on employers where we do not know the founding background but where we do not observe any workers with prior experience working for multinationals. 
Table 4. Transparency and fraction of workers with prior experience in multinationals in firms founded after 1999

\begin{tabular}{|c|c|c|c|}
\hline & (1) & (2) & $(3)$ \\
\hline $\begin{array}{l}\text { Dummy for a non-zero fraction of workers with } \\
\text { prior multinational experience }\end{array}$ & $\begin{array}{c}0.974 * * * \\
(0.343)\end{array}$ & $\begin{array}{l}0.875^{* *} \\
(0.347)\end{array}$ & \\
\hline $\begin{array}{l}\text { Log fraction of workers with prior } \\
\text { multinational experience }\end{array}$ & & & $\begin{array}{l}0.541^{*} \\
(0.293)\end{array}$ \\
\hline Log number of employees & $\begin{array}{c}0.368 * * * \\
(0.099)\end{array}$ & $\begin{array}{c}0.447 * * * \\
(0.150)\end{array}$ & $\begin{array}{c}0.650 * * * \\
(0.235)\end{array}$ \\
\hline Constant & $\begin{array}{c}-16.034 * * * \\
(1.471) \\
\end{array}$ & $\begin{array}{c}-16.539 * * * \\
(2.125) \\
\end{array}$ & $\begin{array}{c}-14.946^{* * * *} \\
(1.980)\end{array}$ \\
\hline Other controls & Yes & Yes & Yes \\
\hline Founding year controls & No & Yes & Yes \\
\hline \# of observations (employers) & $1,278(89)$ & $1,278(89)$ & $1,114(71)$ \\
\hline Adjusted R-squared & 0.117 & 0.125 & 0.123 \\
\hline
\end{tabular}

Notes: The dependent variable is the income-car gap as defined in Table 2. Pooled OLS with robust standard errors clustered by employers in parentheses. $* * *, * *$, and $*$ indicate significance at 1 percent, 5 percent and 10 percent levels, respectively. Excluding car owners with market values of cars in the bottom 20 percent, with incomes not from employment, incomes below the minimum wage and above the equivalent of $\$ 100,000$ in any given year, younger than 18 and older than 60. Other controls in all specifications include 17 dummies for sectors of economic activity, time fixed effects, age, age squared, gender, and percentile in the employer's earning distribution. Specifications I and II include only private domestic companies founded in 1999-2003. Specification II includes 4 dummies for years the company was founded (between 2000 and 2003). Specification III limits the sample to firms that had non-zero fraction of workers with prior multinational experience. 
Table 5. Fraction of workers with prior experience in multinationals and the transparency of "stayers":

Fixed-effect estimates (regression (5))

\begin{tabular}{|c|c|c|c|c|c|c|}
\hline \multirow[b]{2}{*}{ Variables } & $(1)$ & $(2)$ & (3) & $(4)$ & $(5)$ & (6) \\
\hline & \multicolumn{2}{|c|}{$\begin{array}{c}\text { LogIncCar = Log Income }- \\
1 / \lambda \text { Log Car Value }\end{array}$} & \multirow{2}{*}{ DLogIncCar } & \multicolumn{2}{|c|}{$\begin{array}{c}\text { LogIncCar = Log Income }- \\
1 / \lambda \text { Log Car Value }\end{array}$} & DLogIncCar \\
\hline Ownership & Private & Private & & Government & Government & Government \\
\hline $\begin{array}{l}\text { Log fraction of workers with prior } \\
\text { experience in FOF }\end{array}$ & $\begin{array}{l}0.144 * * \\
(0.057)\end{array}$ & & & $\begin{array}{l}-0.013 \\
(0.025)\end{array}$ & & \\
\hline $\begin{array}{l}\text { Fraction of workers with prior } \\
\text { experience in FOF }\end{array}$ & & $\begin{array}{l}12.246 * \\
(6.290)\end{array}$ & & & $\begin{array}{l}-38.236 * \\
(21.949)\end{array}$ & \\
\hline $\begin{array}{l}\text { First difference in log fraction } \\
\text { with prior experience in FOF }\end{array}$ & & & $\begin{array}{c}0.089 * * * \\
(0.032)\end{array}$ & & & $\begin{array}{l}-0.031 \\
(0.019)\end{array}$ \\
\hline Log number of employees & $\begin{array}{l}-0.203 \\
(0.132)\end{array}$ & $\begin{array}{l}-0.227 * \\
(0.133)\end{array}$ & & $\begin{array}{c}0.029 \\
(0.056)\end{array}$ & $\begin{array}{c}0.055 \\
(0.056)\end{array}$ & \\
\hline $\begin{array}{l}\text { First difference in log number of } \\
\text { employees }\end{array}$ & & & $\begin{array}{l}0.270 * * * \\
(0.071)\end{array}$ & & & $\begin{array}{l}0.095 * * * \\
(0.037)\end{array}$ \\
\hline $\begin{array}{l}\text { Percentile in employer earnings } \\
\text { distribution }\end{array}$ & $\begin{array}{l}2.463 * * * \\
(0.235)\end{array}$ & $\begin{array}{l}2.460 * * * \\
(0.235)\end{array}$ & $\begin{array}{l}0.399 * * * \\
(0.088)\end{array}$ & $\begin{array}{l}2.536 * * * \\
(0.122)\end{array}$ & $\begin{array}{l}2.543 * * * \\
(0.122)\end{array}$ & $\begin{array}{c}0.175 * * * \\
(0.052)\end{array}$ \\
\hline Male dummy & & & $\begin{array}{c}0.216 * * * \\
(0.040)\end{array}$ & & & $\begin{array}{c}0.261 * * * \\
(0.024)\end{array}$ \\
\hline Constant & $\begin{array}{c}-15.344 * * * \\
(1.001)\end{array}$ & $\begin{array}{c}-16.134 * * * \\
(0.958)\end{array}$ & $\begin{array}{l}-0.042 \\
(0.095) \\
\end{array}$ & $\begin{array}{c}-18.032 * * * \\
(0.519)\end{array}$ & $\begin{array}{c}-18.135 * * * \\
(0.497)\end{array}$ & $\begin{array}{c}0.006 \\
(0.058) \\
\end{array}$ \\
\hline Employer X individual FE & Yes & Yes & Yes & Yes & Yes & Yes \\
\hline Observations & 30,414 & 30,414 & 13,337 & 53,506 & 53,506 & 27,055 \\
\hline R-squared & 0.947 & 0.947 & 0.023 & 0.945 & 0.945 & 0.013 \\
\hline
\end{tabular}

Notes: The dependent variables are the income-car gap as defined in Table 2 and the first difference in income-car gap as described in the main text. Robust standard errors are reported in parentheses. ***,**, and * indicate significance at $1 \%, 5 \%$, and $10 \%$ respectively. Excluding car owners with market values of cars in the bottom 20 percent, with incomes not from employment, incomes below the minimum wage and above the equivalent of $\$ 100,000$ in any given year, younger than 18 and older than 60 . Sample is limited to workers with no prior experience in foreignowned firms employed by a given employer for two consecutive years. Specifications (1)-(3) are estimated for the sample of employees of domestic private companies, specifications (4)-(6) for employees of government entities and state-owned enterprises. All specifications include employer $\mathrm{X}$ individual and time fixed effects. 
Table 6. Fraction of workers with prior experience in multinationals and the current and future reported incomes and car values of "stayers": Fixed-effect estimates (regression (5))

\begin{tabular}{|c|c|c|c|c|c|c|c|c|}
\hline Variables & $\begin{array}{c}\log \\
\text { income } \mathrm{t}\end{array}$ & $\begin{array}{l}\log \\
\text { income } t+1\end{array}$ & $\begin{array}{c}\text { (3) } \\
\text { Log } \\
\text { market car } \\
\text { value } \mathrm{t}\end{array}$ & $\begin{array}{c}(4) \\
\text { Log market } \\
\text { car value } \\
t+1\end{array}$ & $\begin{array}{c}\text { Log income } \\
\mathrm{t}\end{array}$ & $\begin{array}{c}\text { Log income } \\
t+1\end{array}$ & $\begin{array}{l}\text { Log market } \\
\text { car value } t\end{array}$ & $\begin{array}{l}\text { Log market } \\
\text { car value } t+1\end{array}$ \\
\hline Ownership & Private & Private & Private & Private & Government & Government & Government & Government \\
\hline Log fraction of workers with & $0.077 * * *$ & 0.082 & -0.023 & -0.013 & 0.004 & 0.027 & 0.006 & -0.019 \\
\hline prior experience in FOF at $\mathrm{t}$ & $(0.018)$ & $(0.057)$ & $(0.019)$ & $(0.034)$ & $(0.004)$ & $(0.021)$ & $(0.009)$ & $(0.015)$ \\
\hline \multirow{2}{*}{ Log number of employees } & $-0.167 * * *$ & 0.109 & 0.013 & 0.104 & -0.020 & $0.079 *$ & -0.017 & 0.006 \\
\hline & $(0.042)$ & $(0.173)$ & $(0.045)$ & $(0.132)$ & $(0.014)$ & $(0.048)$ & $(0.019)$ & $(0.028)$ \\
\hline Percentile in employer & $2.745 * * *$ & 0.286 & 0.099 & -0.034 & $2.544 * * *$ & $0.419 *$ & 0.003 & -0.098 \\
\hline earnings distribution & $(0.096)$ & $(0.390)$ & $(0.076)$ & $(0.193)$ & $(0.046)$ & $(0.220)$ & $(0.039)$ & $(0.083)$ \\
\hline \multirow[t]{2}{*}{ Constant } & $6.553 * * *$ & $6.884 * * *$ & $7.664 * * *$ & $7.057 * * *$ & $5.206 * * *$ & $6.355^{* * *} *$ & $8.133 * * *$ & $7.683 * * *$ \\
\hline & $(0.317)$ & $(1.189)$ & $(0.335)$ & $(0.928)$ & $(0.125)$ & $(0.432)$ & $(0.175)$ & $(0.260)$ \\
\hline Employer X individual FE & Yes & Yes & Yes & Yes & Yes & Yes & Yes & Yes \\
\hline Observations & 30,414 & 10,491 & 30,414 & 10,491 & 53,506 & 21,565 & 53,506 & 21,565 \\
\hline R-squared & 0.985 & 0.962 & 0.942 & 0.951 & 0.989 & 0.951 & 0.936 & 0.948 \\
\hline
\end{tabular}

Notes: Robust standard errors are reported in parentheses. ***, **, and * indicate significance at $1 \%, 5 \%$, and $10 \%$ respectively. Excluding car owners with market values of cars in the bottom 20 percent, with incomes not from employment, incomes below the minimum wage and above the equivalent of \$100,000 in any given year, younger than 18 and older than 60. Sample is limited to workers with no prior experience in foreignowned firms employed by a given employer for two consecutive years. Specifications (1)-(4) are estimated for the sample of employees of domestic private companies, specifications (5)-(8) for employees of government entities and state-owned enterprises. All specifications include employer $\mathrm{X}$ individual and time fixed effects. 
Table 7. Reported incomes, car values and percentiles in employer earnings distribution (EED) by different categories of workers.

\begin{tabular}{|c|c|c|c|c|c|c|c|c|c|}
\hline \multirow[b]{2}{*}{ Employer } & \multicolumn{2}{|c|}{ Reported incomes } & \multicolumn{2}{|c|}{ Car values } & \multicolumn{2}{|c|}{$\begin{array}{l}\text { Car values } \\
\text { /incomes }\end{array}$} & \multicolumn{2}{|c|}{$\begin{array}{l}\text { Percentile in } \\
\text { employer ED }\end{array}$} & \multirow[t]{2}{*}{$\begin{array}{l}\text { Number of } \\
\text { individuals }\end{array}$} \\
\hline & $\mathrm{t}-1$ & $\mathrm{t}$ & $\mathrm{t}-1$ & $\mathrm{t}$ & $\mathrm{t}-1$ & $\mathrm{t}$ & $t-1$ & $\mathrm{t}$ & \\
\hline $\begin{array}{l}\text { Foreign-owned in } \mathrm{t}-1 \text {, } \\
\text { domestic in } \mathrm{t}\end{array}$ & $\begin{array}{r}8,263 \\
(11,310)\end{array}$ & $\begin{array}{r}4,495 \\
(9,146)\end{array}$ & $\begin{array}{r}7,405 \\
(8,696)\end{array}$ & $\begin{array}{r}7,525 \\
(10,374)\end{array}$ & 0.90 & 1.67 & $\begin{array}{r}0.524 \\
(0.273)\end{array}$ & $\begin{array}{r}0.591 \\
(0.286)\end{array}$ & 123 \\
\hline $\begin{array}{l}\text { Domestic in } \mathrm{t}-1, \mathrm{t} \\
\text { (same employer) }\end{array}$ & $\begin{array}{r}3,498 \\
(5,876)\end{array}$ & $\begin{array}{r}4,403 \\
(7,109)\end{array}$ & $\begin{array}{r}6,790 \\
(10,050)\end{array}$ & $\begin{array}{r}7,175 \\
(11,857)\end{array}$ & 1.94 & 1.63 & $\begin{array}{r}0.734 \\
(0.227)\end{array}$ & $\begin{array}{r}0.741 \\
(0.223)\end{array}$ & 67,588 \\
\hline $\begin{array}{l}\text { Domestic in } \mathrm{t}-1, \mathrm{t} \\
\text { (new employer at } \mathrm{t} \text { ) }\end{array}$ & $\begin{array}{r}2,904 \\
(6,250)\end{array}$ & $\begin{array}{r}3,532 \\
(7,134)\end{array}$ & $\begin{array}{r}7,052 \\
(10,682)\end{array}$ & $\begin{array}{r}6,995 \\
(10,228)\end{array}$ & 2.43 & 1.98 & $\begin{array}{r}0.661 \\
(0.264)\end{array}$ & $\begin{array}{r}0.625 \\
(0.263)\end{array}$ & 3,199 \\
\hline $\begin{array}{l}\text { Foreign-owned in } \mathrm{t}-1 \text {, } \\
\mathrm{t} \text { (same employer) }\end{array}$ & $\begin{array}{r}15,565 \\
(14,656)\end{array}$ & $\begin{array}{r}17,679 \\
(16,398)\end{array}$ & $\begin{array}{r}7,143 \\
(8,378)\end{array}$ & $\begin{array}{r}7,513 \\
(9,559)\end{array}$ & 0.46 & 0.42 & $\begin{array}{r}0.689 \\
(0.232)\end{array}$ & $\begin{array}{r}0.707 \\
(0.229)\end{array}$ & 6,303 \\
\hline $\begin{array}{l}\text { Foreign-owned in } \mathrm{t}-1 \text {, } \\
\mathrm{t} \text { (new employer at } \mathrm{t} \text { ) }\end{array}$ & $\begin{array}{r}18,779 \\
(16,185)\end{array}$ & $\begin{array}{r}18,444 \\
(16,464)\end{array}$ & $\begin{array}{r}7,964 \\
(8,635)\end{array}$ & $\begin{array}{r}8,901 \\
(10,719)\end{array}$ & 0.42 & 0.48 & $\begin{array}{r}0.665 \\
(0.230)\end{array}$ & $\begin{array}{r}0.660 \\
(0.232)\end{array}$ & 312 \\
\hline $\begin{array}{l}\text { Domestic in } \mathrm{t}-1, \\
\text { Foreign-owned in } \mathrm{t}\end{array}$ & $\begin{array}{r}4,748 \\
(11,444) \\
\end{array}$ & $\begin{array}{r}8,618 \\
(11,111) \\
\end{array}$ & $\begin{array}{r}6,038 \\
(6,266) \\
\end{array}$ & $\begin{array}{r}6,006 \\
(6,586) \\
\end{array}$ & 1.27 & 0.70 & $\begin{array}{r}0.620 \\
(0.282) \\
\end{array}$ & $\begin{array}{r}0.530 \\
(0.285) \\
\end{array}$ & 154 \\
\hline
\end{tabular}

Source: Authors' estimates using Moscow income and car registry databases for 1999-2003. The sample is limited to car owners with at least two consecutive years of observation, excluding those with market values of cars in the bottom 20 percent, with incomes not from employment, incomes below the minimum wage and above the equivalent of $\$ 100,000$ in any given year, younger than 18 and older than 60 . All values in 1999 US dollars using market exchange rates between the US dollar and the ruble and adjusted for inflation using the US Consumer Price Index. Standard deviations in parentheses. 
Table 8. Estimations of regression (6) on four samples of domestic private employers

\begin{tabular}{lcccc}
\hline \hline Variables & $(1)$ & $(2)$ & $(3)$ & $(4)$ \\
\hline Dummy for employed by & 0.070 & 0.290 & $0.915^{*}$ & $1.679^{* *}$ \\
foreign-owned firm in $t-1$ & $(0.267)$ & $(0.354)$ & $(0.515)$ & $(0.763)$ \\
Age & $0.027^{* * *}$ & $0.029^{* * *}$ & 0.022 & 0.011 \\
& $(0.001)$ & $(0.005)$ & $(0.019)$ & $(0.011)$ \\
Male dummy & 0.048 & -0.186 & 0.044 & -0.211 \\
& $(0.033)$ & $(0.113)$ & $(0.306)$ & $(0.260)$ \\
Percentile in employer & $1.637^{* * *}$ & $0.854^{* * *}$ & 0.263 & $0.826^{*}$ \\
EED & $(0.055)$ & $(0.240)$ & $(0.631)$ & $(0.430)$ \\
Log number of employees & $0.316^{* * *}$ & $0.301^{* * *}$ & $0.716^{* * *}$ & $0.237^{*}$ \\
& $(0.008)$ & $(0.039)$ & $(0.142)$ & $(0.128)$ \\
Constant & $-20.362^{* * *}$ & $-19.246^{* * *}$ & $-20.321^{* * *}$ & $-16.945^{* * *}$ \\
& $(0.091)$ & $(0.410)$ & $(1.220)$ & $(0.874)$ \\
\hline Other controls & Yes & Yes & Yes & Yes \\
Number of observations & 67,504 & 3,877 & 370 & 1,020 \\
Adjusted R-squared & 0.111 & 0.068 & 0.118 & 0.118 \\
\hline \hline
\end{tabular}

Notes: The dependent variable is the income-car gap as defined in Table 2. Pooled OLS with robust standard errors reported in parentheses. $* * *, * *$, and $*$ indicate significance at $1 \%, 5 \%$, and $10 \%$ respectively. Excluding car owners with market values of cars in the bottom 20 percent, with incomes not from employment, incomes below the minimum wage and above the equivalent of $\$ 100,000$ in any given year, younger than 18 and older than 60 in both $t-1$ and $t$. Sample is limited to workers who moved from a foreign-owned firm to a domestic private firm between $t-1$ and $t$ or who were employed with the same domestic private firm for two consecutive years and had no prior experience in foreign-owned firms. Column II limits the sample to employers with the overall fraction of workers with prior experience working for foreign-owned firms above the $90^{\text {th }}$ percentile (greater or equal than 0.0104), column III limits the sample to employers with the overall fraction of workers with prior experience working for foreign-owned firms above the $99^{\text {th }}$ percentile (greater or equal than 0.0465), column IV limits the sample to employers founded in partnership with foreign capital as explained in Section 3.2.1. All specifications include 17 dummies for sectors of economic activity, along with time fixed effects. 
Table 9. Estimations of regression (7): employer $\mathrm{X}$ individual fixed-effects

\begin{tabular}{|c|c|c|c|c|c|c|}
\hline & $(1)$ & $(2)$ & (3) & (4) & $(5)$ & $(6)$ \\
\hline Percentile distance & $\begin{array}{l}-0.084 \\
(0.127)\end{array}$ & & & & & $\begin{array}{c}0.252 \\
(0.634)\end{array}$ \\
\hline Percentile distance (last) & & $\begin{array}{l}-0.151 \\
(0.126)\end{array}$ & & & & $\begin{array}{l}-0.195 \\
(0.423)\end{array}$ \\
\hline Percentile distance (car values) & & & $\begin{array}{l}-1.106 * * \\
(0.518)\end{array}$ & & & $\begin{array}{l}-1.105^{* *} \\
(0.544)\end{array}$ \\
\hline $\begin{array}{l}\text { Maximum percentile with a foreign } \\
\text { employer }\end{array}$ & & & & $\begin{array}{c}0.138 \\
(0.108)\end{array}$ & & $\begin{array}{c}0.406 \\
(0.689)\end{array}$ \\
\hline $\begin{array}{l}\text { Dummy for a mover from a foreign } \\
\text { employer above }\end{array}$ & & & & & $\begin{array}{c}0.091 \\
(0.066)\end{array}$ & $\begin{array}{c}0.045 \\
(0.258)\end{array}$ \\
\hline log number employees & $\begin{array}{l}-0.250^{*} \\
(0.133)\end{array}$ & $\begin{array}{l}-0.221 \\
(0.139)\end{array}$ & $\begin{array}{l}-0.151 \\
(0.403)\end{array}$ & $\begin{array}{l}-0.254^{*} \\
(0.133)\end{array}$ & $\begin{array}{l}-0.250^{*} \\
(0.133)\end{array}$ & $\begin{array}{l}-0.284 \\
(0.409)\end{array}$ \\
\hline Percentile in EED & $\begin{array}{c}2.500 * * * \\
(0.238)\end{array}$ & $\begin{array}{c}2.550 * * * \\
(0.244)\end{array}$ & $\begin{array}{c}2.576 * * * \\
(0.745)\end{array}$ & $\begin{array}{c}2.450 * * * \\
(0.235)\end{array}$ & $\begin{array}{c}2.546 * * * \\
(0.243)\end{array}$ & $\begin{array}{l}2.603 * * * \\
(0.766)\end{array}$ \\
\hline Constant & $\begin{array}{c}-15.896 * * * \\
(0.958)\end{array}$ & $\begin{array}{c}-16.121 * * * \\
(1.005)\end{array}$ & $\begin{array}{c}-16.735 * * * \\
(2.900)\end{array}$ & $\begin{array}{c}-15.930 * * * \\
(0.953)\end{array}$ & $\begin{array}{c}-15.989 * * * \\
(0.952)\end{array}$ & $\begin{array}{c}-15.929 * * * \\
(3.026)\end{array}$ \\
\hline Observations & 30,333 & 28,665 & 10,029 & 30,414 & 30,414 & 9,583 \\
\hline R-squared & 0.947 & 0.947 & 0.965 & 0.947 & 0.947 & 0.965 \\
\hline Employer X Individual FE & Yes & Yes & Yes & Yes & Yes & Yes \\
\hline
\end{tabular}

Notes: The dependent variable is the income-car gap as defined in Table 2. Excluding car owners with market values of cars in the bottom 20 percent, with incomes not from employment, incomes below the minimum wage and above the equivalent of $\$ 100,000$ in any given year, younger than 18 and older than 60. Sample is limited to those who continued employment at a given private domestic employer. "Percentile distance" is the difference between individual wage percentile and wage percentile of closest mover from a foreign-owned company at the current employer. "Percentile distance (last)" uses wage percentile at the previous (foreign-owned) employer for movers. "Percentile distance (cars)" uses percentiles in car values. These three are our measures of horizontal spillovers. "Maximum percentile with a foreign employer" and "Dummy for a mover from a foreign employer above" measure vertical spillovers. "Maximum percentile with a foreign employer" is the maximum percentile occupied by employee with prior working experience at a foreign-owned company in a given domestic company. "Dummy for a mover from a foreign employer above" is a dummy variable indicating whether for a current employee there is a mover from a foreign-owned company who is higher according to wage percentile in the current employer. See the main text for details. All specifications include employer X individual and time fixed effects. Robust standard errors are reported in parentheses. $* * *, * *$, and * indicate significance at $1 \%, 5 \%$, and $10 \%$ respectively. 
Table 10. Estimations of regression (7): controlling for fraction of workers with prior experience in foreign-owned firms

\begin{tabular}{|c|c|c|c|c|c|c|}
\hline & (1) & $(2)$ & $(3)$ & (4) & $(5)$ & $(6)$ \\
\hline Log fraction of workers with & $0.139 * *$ & $0.115^{*}$ & 0.210 & $0.136 * *$ & $0.135 * *$ & 0.039 \\
\hline prior experience in $\mathrm{FOF}$ & $(0.058)$ & $(0.061)$ & $(0.214)$ & $(0.058)$ & $(0.057)$ & $(0.231)$ \\
\hline Percentile distance & $\begin{array}{l}-0.002 \\
(0.129)\end{array}$ & & & & & \\
\hline Percentile distance (last) & & $\begin{array}{l}-0.072 \\
(0.132)\end{array}$ & & & & $\begin{array}{l}-0.169 \\
(0.430)\end{array}$ \\
\hline $\begin{array}{l}\text { Percentile distance (car } \\
\text { values) }\end{array}$ & & & $\begin{array}{c}-1.069 * * \\
(0.512)\end{array}$ & & & $\begin{array}{c}-1.083 * * \\
(0.540)\end{array}$ \\
\hline Maximum percentile with a & & & & 0.060 & & 0.221 \\
\hline foreign employer & & & & $(0.110)$ & & $(0.446)$ \\
\hline Dummy for a mover from a & & & & & 0.055 & 0.071 \\
\hline foreign employer above & & & & & $(0.066)$ & $(0.244)$ \\
\hline \multirow[t]{2}{*}{ Log number of employees } & -0.202 & -0.182 & -0.169 & -0.207 & -0.206 & -0.286 \\
\hline & $(0.133)$ & $(0.139)$ & $(0.404)$ & $(0.133)$ & $(0.133)$ & $(0.410)$ \\
\hline \multirow[t]{2}{*}{ Percentile in EED } & $2.483 * * *$ & $2.528 * * *$ & $2.547 * * *$ & $2.458 * * *$ & $2.514 * * *$ & $2.638 * * *$ \\
\hline & $(0.238)$ & $(0.244)$ & $(0.744)$ & $(0.235)$ & $(0.243)$ & $(0.762)$ \\
\hline \multirow[t]{2}{*}{ Constant } & $-15.384 * * *$ & $-15.697 * * *$ & $-15.336 * * *$ & $-15.384 * * *$ & $-15.429 * * *$ & $-15.553 * * *$ \\
\hline & $(0.998)$ & $(1.050)$ & $(3.191)$ & $(1.001)$ & $(1.002)$ & $(3.198)$ \\
\hline Employer X Individual FE & Yes & Yes & Yes & Yes & Yes & Yes \\
\hline Observations & 30,333 & 28,665 & 10,029 & 30,414 & 30,414 & 9,600 \\
\hline R-squared & 0.947 & 0.947 & 0.965 & 0.947 & 0.947 & 0.965 \\
\hline
\end{tabular}

Notes: The dependent variable is the income-car gap as defined in Table 2. Excluding car owners with market values of cars in the bottom 20 percent, with incomes not from employment, incomes below the minimum wage and above the equivalent of $\$ 100,000$ in any given year, younger than 18 and older than 60. Sample is limited to those who continued employment at a given private domestic employer. See notes to Table 9 for the explanation of variables. All specifications include employer X individual and time fixed effects. Robust standard errors are reported in parentheses. $* * *, * *$, and $*$ indicate significance at $1 \%, 5 \%$, and $10 \%$ respectively. 
Table 11: Robustness: Fixed-effect estimates of regression (5) with different income elasticities of the demand for the stock of cars

\begin{tabular}{lcccccc}
\hline \hline Variables & \multicolumn{5}{c}{ Dependent variable: LogIncCar $=$ Log Income $-1 / \lambda$ Log Car Value } \\
\hline Ownership & Private & Private & Private & Government & Government & Government \\
Log fraction of workers with prior & $0.171^{* *}$ & $0.144^{* *}$ & $0.129^{* * *}$ & -0.019 & -0.013 & -0.009 \\
experience in FOF & $(0.078)$ & $(0.057)$ & $(0.046)$ & $(0.034)$ & $(0.025)$ & $(0.019)$ \\
& -0.217 & -0.203 & $-0.195^{*}$ & 0.049 & 0.029 & 0.018 \\
Log number of employees & $(0.182)$ & $(0.132)$ & $(0.106)$ & $(0.077)$ & $(0.056)$ & $(0.045)$ \\
Percentile in employer earnings & $2.350^{* * *}$ & $2.463^{* * *}$ & $2.526^{* * *}$ & $2.533^{* * *}$ & $2.536^{* * *}$ & $2.538^{* * *}$ \\
distribution & $(0.317)$ & $(0.235)$ & $(0.192)$ & $(0.164)$ & $(0.122)$ & $(0.100)$ \\
& $-24.103^{* * *}$ & $-15.344^{* * *}$ & $-10.478^{* * *}$ & $-27.328^{* * *}$ & $-18.032^{* * *}$ & $-12.868^{* * *}$ \\
Constant & $(1.369)$ & $(1.001)$ & $(0.802)$ & $(0.714)$ & $(0.519)$ & $(0.412)$ \\
\hline Employer X Individual FE & Yes & Yes & Yes & Yes & Yes & Yes \\
Elasticity parameter $\lambda$ & 0.25 & 0.35 & 0.45 & 0.25 & 0.35 & 0.45 \\
Observations & 30,414 & 30,414 & 30,414 & 53,506 & 53,506 & 53,506 \\
R-squared & 0.944 & 0.947 & 0.952 & 0.940 & 0.945 & 0.949 \\
\hline \hline
\end{tabular}

Notes: The dependent variable is the income-car gap as defined in Table 2. Robust standard errors are reported in parentheses. ***, **, and * indicate significance at $1 \%, 5 \%$, and $10 \%$ respectively. Excluding car owners with market values of cars in the bottom 20 percent, with incomes not from employment, incomes below the minimum wage and above the equivalent of $\$ 100,000$ in any given year, younger than 18 and older than 60. Sample is limited to workers with no prior experience in foreign-owned firms employed by a given employer for two consecutive years. Specifications (1)-(3) are estimated for the sample of employees of domestic private companies, specifications (4)-(6) for employees of government entities and state-owned enterprises. All specifications include employer X individual and time fixed effects. 
Table 12. Robustness: Fraction of workers with prior experience in multinationals and the transparency of "stayers": Fixed-effect estimates (regression (5)) on the sample of employers present in all five databases

\begin{tabular}{|c|c|c|c|c|c|c|}
\hline \multirow{3}{*}{$\begin{array}{l}\text { Variables } \\
\text { Ownership } \\
\text { Log fraction of workers with prior } \\
\text { experience in FOF }\end{array}$} & \multicolumn{2}{|c|}{$\begin{array}{c}(1) \\
\text { LogIncCar }=\text { Log Income }- \\
1 / \lambda \text { Log Car Value }\end{array}$} & \multirow{2}{*}{$\begin{array}{c}\text { DLogIncCar } \\
\text { Private }\end{array}$} & \multicolumn{2}{|c|}{$\begin{array}{c}(4) \\
\text { LogIncCar = Log Income - } \\
1 / \lambda \text { Log Car Value }\end{array}$} & \multirow{2}{*}{$\begin{array}{c}(6) \\
\text { DLogIncCar } \\
\text { Government }\end{array}$} \\
\hline & Private & Private & & Government & Government & \\
\hline & $\begin{array}{c}0.114 * * \\
(0.058)\end{array}$ & & & $\begin{array}{l}-0.039 \\
(0.026)\end{array}$ & & \\
\hline $\begin{array}{l}\text { Fraction of workers with prior } \\
\text { experience in FOF }\end{array}$ & & $\begin{array}{c}21.469 * * \\
(10.647)\end{array}$ & & & $\begin{array}{l}-22.457 \\
(21.476)\end{array}$ & \\
\hline $\begin{array}{l}\text { First difference in log fraction } \\
\text { with prior experience in FOF }\end{array}$ & & & $\begin{array}{c}0.068^{* *} \\
(0.030)\end{array}$ & & & $\begin{array}{l}-0.030^{*} \\
(0.016)\end{array}$ \\
\hline Log number of employees & $\begin{array}{l}-0.155 \\
(0.137)\end{array}$ & $\begin{array}{l}-0.171 \\
(0.137)\end{array}$ & & $\begin{array}{c}0.017 \\
(0.057)\end{array}$ & $\begin{array}{c}0.042 \\
(0.057)\end{array}$ & \\
\hline $\begin{array}{l}\text { First difference in log number of } \\
\text { employees }\end{array}$ & & & $\begin{array}{l}0.162 * * \\
(0.077)\end{array}$ & & & $\begin{array}{c}0.079 * * * \\
(0.029)\end{array}$ \\
\hline $\begin{array}{l}\text { Percentile in employer earnings } \\
\text { distribution }\end{array}$ & $\begin{array}{l}2.456 * * * \\
(0.233)\end{array}$ & $\begin{array}{l}2.443 * * * \\
(0.233)\end{array}$ & $\begin{array}{c}0.295 * * * \\
(0.087)\end{array}$ & $\begin{array}{l}2.488 * * * \\
(0.125)\end{array}$ & $\begin{array}{l}2.494 * * * \\
(0.125)\end{array}$ & $\begin{array}{c}0.177 * * * \\
(0.046)\end{array}$ \\
\hline Male dummy & & & $\begin{array}{l}0.170 * * * \\
(0.040)\end{array}$ & & & $\begin{array}{l}0.225 * * * \\
(0.020)\end{array}$ \\
\hline Constant & $\begin{array}{c}-14.434 * * * \\
(1.065) \\
\end{array}$ & $\begin{array}{c}-15.130 * * * \\
(1.011) \\
\end{array}$ & $\begin{array}{c}0.107 \\
(0.096) \\
\end{array}$ & $\begin{array}{c}-16.630 * * * \\
(0.543) \\
\end{array}$ & $\begin{array}{c}-16.533 * * * \\
(0.519) \\
\end{array}$ & $\begin{array}{c}0.153 * * * \\
(0.050)\end{array}$ \\
\hline Employer X individual FE & Yes & Yes & Yes & Yes & Yes & Yes \\
\hline Observations & 27,476 & 27,476 & 12,302 & 58,903 & 58,903 & 31,155 \\
\hline R-squared & 0.947 & 0.947 & 0.017 & 0.952 & 0.952 & 0.011 \\
\hline
\end{tabular}

Notes: The dependent variables are the income-car gap as defined in Table 2 and the first difference in Income-car gap as described in the main text. Robust standard errors are reported in parentheses. $* * *, * *$, and * indicate significance at 1\%, 5\%, and 10\% respectively. Excluding car owners with market values of cars in the bottom 20 percent, with incomes not from employment, incomes below the minimum wage and above the equivalent of $\$ 100,000$ in any given year, younger than 18 and older than 60 . Sample is limited to workers with no prior experience in foreignowned firms employed by a given employer for two consecutive years. Specifications (1)-(4) are estimated for the sample of employees of domestic private companies, specifications (5)-(8) for employees of government entities and state-owned enterprises. All specifications include employer $\mathrm{X}$ individual and time fixed effects. 


\section{Appendix 1. Details About the Data and Sample Construction}

\section{Data sources}

We employed two separate sets of data.

Vehicle Registration Database, 2005: Contains the list of all recorded instances of vehicle registrations in Moscow as of April 2005, along with the corresponding list of owners. The former provides the detailed description of vehicle characteristics including model, make, year of manufacturing, license plate number, unique Vehicle Identifying Number (VIN), and the date of registration. The latter contains data on each owner's full name, date of birth, residential address and passport number. Each entry in the vehicle database represents an instance of registration. Repeated registrations of the same vehicle are recorded as separate entries. We therefore define continuous periods of ownership for each car as intervals between its consecutive registrations by distinct owners. And to find all relevant entries that correspond to a given car we use its VIN number. The total number of raw entries is $8,308,881$ vehicle registrations and 8,141,122 owners.

Administrative Databases of Income, 1999-2003: This is a collection of five separate databases filed by all registered employers (sources of income) in Moscow for their employees (recipients of income). Each database covers one year between 1999-2003. Individual records in all of the five files provide full names, dates of birth, personal tax IDs, passport numbers, residential addresses, annual gross and taxable incomes, employers' names and employers' state-issued registration IDs. The total number of raw entries in each database is as follows: 8,711,103 (1999); 10,361,320 (2000); 10,019,144 (2001); 7,029,376 (2002); 9,355,493 (2003).

\section{Data issues}

All datasets above appear to have originated from manually digitized paper-based records and that leads to the following common problems:

Errors and missing data: A substantial number of entries contain artifacts of manual input: violations of the format, misspellings, typos, idiosyncratic abbreviations, missing data in certain fields, etc. This poses a challenge for matching entries across databases, as it reduces the amount and reliability of identifying information. As a result, we were not able to positively identify all legitimate matches, however, due to the random nature of imperfections in the data, we do not expect these missing matches to cause any systematic bias in our estimates.

Duplicate entries: We found that approximately 10 percent of all entries in our datasets are in fact virtual duplicates of some other entries contained in the same files. Some of them are fully identical to (and are thus indistinguishable from) the originals; the rest have slight modifications compared to the originals, caused usually by typos or partially missing data. As explained in the main text, we decided to use only those individuals for whom we had only one entry in each of the income databases, thus eliminating all individuals with duplicate entries (as well as those with multiple sources of income in any year). 


\section{Detailed sample construction procedure}

We first used combinations of full name, date of birth and address to provisionally match individuals in income databases for different years and to their vehicle ownership records. We then used additional identifying information (personal tax ID, passport number, etc.) available in those matched records to find other matches that were not identified before. Finally, in our working sample we kept only the individuals that had at most one entry in any of the five income databases.

In more detail, the selection procedure was as follows:

Step 1: We started by eliminating poor quality data from all databases to increase the efficiency of subsequent matching. Specifically, we left out all entries that either had inconsistencies in full names (abbreviations, obvious typos or non-alphabetic characters), or lacked information on the date of birth, or address.

Step 2: We then used the five income databases to create linking tables that established connections between the same individuals within each database and between each pair of them. This process relied on the iterative matching procedure that leveraged all individual identifying information found in preceding iterations when searching for other possible matches in subsequent iterations.

Step 3: Based on the linking tables obtained in the previous step, we created five crosssections of "single-entry" individuals, separately for each of the five years from 19992003. More precisely, an individual was left in the sample if (1) he or she was present exactly one time in the database for a given year (no other related entries in that year) and (2) he or she had at most one related entry in each of the remaining four databases. This sample, consisting of about 26.9 million observations (about 60 percent of all initial raw entries in all 5 income databases), was used to calculate various employer-specific variables, such as the multinational fraction, used in the estimations in the main text.

Step 4: The auto registry database was used to match owners to all of their vehicles. If an individual owned multiple vehicles, the market values of all such vehicles (assigned as explained in Appendix 2 below) were added together. We then matched car owners with "single-entry" individuals in each of the five income databases obtained in the previous step. This produced 2,913,359 matched observations on individuals who owned at least one car in at least one of the five years from 1999-2003 and were present in at least one of the "single-entry" income databases as explained in the previous step. From this sample of all car owners matched to their income records we constructed the sample used for estimation purposes by eliminating cars with missing VINs for which we could not determine the exact time period during which an individual owned a given car.

\section{Research variables}

For each individual in our sample we were able to directly obtain the following information about research variables used in estimation: age (from the information about the date of birth), name and state-issued registration ID of the employer (income source) for 1999-2003; the amount of income earned (received) from the employer (income source); make, model and year of all owned cars (if any); estimated market value of all owned cars (if any) as imputed using the procedure explained in Appendix 2.

In addition, we created the following research variables from the available data: 
Gender: Imputed from gender-specific endings of middle names, which are characteristic of the Russian language.

Sector classification and type of ownership: We classified 14,000 distinct primary employers in our sample into 19 sectors and also assigned each of them to one of the three types of ownership (see Appendix 3 for more details). Namely, we checked the presence of sector-specific keywords (such as bank, insurance, factory, police, etc.) in employers' names to do the initial automatic sector assignment and then manually assigned sectors to the employers that were left out by the script. Similarly, we used another list of keywords to infer the type of ownership (e. g. JSC, Ltd, State, etc.) and we used the website http:/querycom.ru/ which provided ownership information for companies using their state-issued registration IDs we have in our data. We then manually resolved all the remaining undetermined cases and also manually checked all companies provisionally classified as foreign-owned to determine whether it was owned by a western corporation or was an offshore controlled by Russian capital.

Employer Size: This was obtained by counting the total number of individuals who received payments from a given employer (income source) in a given year.

Percentile in Employer Earnings Distribution (EED): This was obtained as the percentile of an individual's income in the overall earnings distribution of his/her employer in a given year.

Even though all the data used by us came from the public domain, to ensure privacy we have purged all the individual identifying information (names, addresses, id numbers) after we finished the construction of the sample. All the data used in the paper (without individual identifying information) and our estimation codes will be available for the purposes of replicating our results. We can also provide the scripts used to clean the data and to conduct the selection/matching process described in steps 1-4 above, which can be employed to replicate our sample construction procedure using the original databases.

\section{Appendix 2. Imputation of car values}

We develop a procedure to assign prices to the vehicles owned by individuals in our sample. For each car, our data contain the car's make, model and the year it was produced. For example: "Make: Hyundai; Model: Avant; Production year: 1999," or "Make: Jaguar; Model: XJ6; Production year: 1993." No information on the presence of optional features or the vehicle's condition is available. Hence, we could only assign prices to vehicles based on the median market value of cars of the same make, model and year of production. The details of the procedure used to impute prices are described below.

\section{Determining used/new status}

New cars sell at a substantial premium over used cars, so accurately assigning a price to a vehicle requires determining whether it was purchased new or used. To do so, we used Vehicle Identification Numbers (VINs) to search the Vehicle Registration Database and determine the car's date of first registry. We dropped vehicles lacking a valid VIN, but this affected only a relatively small number of older, low-value vehicles. 
We designated a car "new" if it was first registered in the year it was produced and in the name of the current owner. We considered a car "used" if the database showed prior registrations by different owners. We also considered a car "used" if either: (i) it was produced two or more years prior to the date of the first recorded purchase, or (ii) the first recorded purchase occurred after June $30^{\text {th }}$ of the year following the production year. This (somewhat arbitrary) rule applied to less than 5 percent of cars in our sample (these cars also all proved to be relatively dated and therefore heavily depreciated by the time of our analysis). The results are also not sensitive to dropping these cars (and their owners) from the sample.

\section{Obtaining prices}

Russia lacks an authoritative source of car price information analogous to the "Blue Book" in the United States. Instead, we relied upon prices listed on the two large auto-trading websites that were operating in Moscow during 2005 and 2006.

The first website (www.autonet.ru) contained online sales advertisements from various private owners and used-car dealers in Moscow and provided information on a large variety of makes, models and years of production. For the majority of cars in our sample we were able to find multiple matching offers (often more than 10), and we took the median asking price as the market value of the vehicle as of 2005 . We also referred to the second website (www.automosk.ru which is no longer operating) to collect pricing data on the new vehicles in our sample. Whenever we could not find a price for a given combination of make, model, and production year, we used the most similar model available. For example, for 2003 Mercedes models 200 and 200E, we used the price of the 2003 Mercedes model 200D.

We use these data to estimate an exponential depreciation rate, as well as category-specific new-car premiums for seven classes of vehicles: 1) Luxury models, 2) German and Swedish cars, 3) Japanese cars, 4) American cars 5) other European (nonGerman or Swedish) cars, 6) Russian cars, and 7) Korean and Chinese cars (the full inventory of models and category assignments is available upon request).

To estimate category-specific new car premiums and the annual depreciation rate we employed the universe of about 1,043 car make/model/year prices we gathered from the on-line sites above, which contained information for the same make/model for different years.

Formally, let $X_{i n}^{s t}$ denote the price of a car of make-model $i$, of used status, produced in year $s$, observed in year $t$. We assume that this price is given by

$$
X_{i n}^{s t}=\bar{X}_{i} \exp \left\{-\delta(t-s)-\gamma_{k_{i}}+\varepsilon_{i n}^{s t}\right\}
$$

where $\bar{X}_{i}$ is the price of a new car of make model $i, \gamma_{k_{i}}$ is the new car premium for the category into which make-model $i$ falls, $\delta$ denotes the depreciation rate, and $\varepsilon_{i n}^{s t}$ is the error term. Taking logs, we obtain the regression model:

$$
\ln X_{i n}^{s t}=\ln \bar{X}_{i}-\delta(t-s)-\gamma_{k i}+\varepsilon_{i n}^{s t}(*)
$$

We have information for the same car make/model $i$ for different years, denote $\mathrm{t}^{*}(i)$ the most recent year of observation for car make/model $i$. Denote $n(i)$ indicator for whether the price $X_{i n}^{s^{*}(i)}$ we observed in this most recent year was for a new car (this implies $\left.\mathrm{t}^{*}(i)=s\right)$. 
Subtracting $\quad \ln X_{i n}^{s *^{*}(i)}=\ln \bar{X}_{i}-\gamma_{k}(1-D(n=1))-\delta\left(t^{*}(i)-s\right)+\varepsilon_{t^{*}(i), i} \quad$ from $\quad$ equation above we get the equation:

$$
\ln X_{i n}^{s t}-\ln X_{i n}^{s *(i)}=-\delta\left(t-t^{*}(i)\right)-\gamma_{k i} D(n=1)+\varepsilon_{i n}^{s t},
$$

which we estimate by ordinary least squares. The depreciation rate and category-specific new car premiums estimates are presented in Table A1.1. We also experimented with category-specific depreciation rates, but the results were very similar.

Table A2.1. Estimated new car premium and depreciation coefficients for different categories of cars

\begin{tabular}{lllll}
\hline \hline Variable & Coefficient & Std. Err. & t-value & $\mathrm{P}>\mathrm{t}$ \\
\hline New car premium & & & & \\
$\quad$ Luxury & 0.353 & 0.019 & 18.69 & 0.000 \\
Russian & 0.097 & 0.022 & 4.36 & 0.000 \\
German & 0.182 & 0.031 & 5.87 & 0.000 \\
Japanese & 0.111 & 0.024 & 4.59 & 0.000 \\
American & 0.076 & 0.046 & 1.66 & 0.098 \\
Korean/Chinese & 0.026 & 0.037 & 0.69 & 0.489 \\
European & 0.180 & 0.039 & 4.64 & 0.000 \\
Depreciation for & & & & \\
Each additional year & 0.123 & 0.002 & 72.94 & 0.000 \\
\hline \hline
\end{tabular}

R-squared: 0.929, Number of observations: 1,043

For each car make/model in our data we find baseline price using car auction websites above. Then we use estimated depreciation rates and new car premiums estimated above to compute the estimated price $\hat{X}_{i n}^{s t}$ of all make-model-year combinations in our data, taking into account also if the car was purchased new or used.

\section{Appendix 3. Sectoral breakdown of the data and comparisons between the data on classified versus unclassified employers (income sources)}

In this appendix we compare our data on classified part of the Moscow workforce with the rest of the data and also present the details of the breakdown of the sample by sectors of economic activity.

As already mentioned (see Section III in the main text), the total number of observations in our data after the procedure described in Appendix 1 is 26,889,790, or about half of all raw entries in five income-tax databases. Among these, we identified the observation as that on a car owner in 1,604,231 cases ( 6 percent of total) by positively matching the individual in an income-tax database with his or her vehicle in the auto registry. The fraction of car owners seems to be lower than the official statistics, which put the car ownership rate in Moscow at about 20 percent in the late 1990s - early 2000s. 
Partly this is no doubt due to the difficulties involved in identifying potential matches but since there is no reason to suspect any systematic bias coming from bad data, we think that we have a representative sample of car owners in Moscow that probably comprise about a quarter of the population.

As also mentioned in Section III, we obtained classification of employers by ownership and sector of economic activity for the total of 13,613,869 observations, leaving 13,290,321 observations employed by entities whose ownership and sector of activity we don't know. Table A3.1 compares the number of observations on classified and unclassified employers sliced by the number of years for which the employer itself (as identified by the unique employer identification number) is present in the data.

Table A3.1. Classified and unclassified employers

\begin{tabular}{|c|c|c|c|c|}
\hline \multirow[b]{2}{*}{ Years employer observed in data } & \multicolumn{4}{|c|}{ Number of observations in the data } \\
\hline & Private & Government & Foreign & Unclassified \\
\hline 1 & 190,090 & 151,876 & 11,139 & 955,192 \\
\hline 2 & 192,324 & 225,933 & 6,831 & $1,656,037$ \\
\hline 3 & 444,449 & 422,136 & 23,071 & $3,833,991$ \\
\hline 4 & 972,577 & 725,505 & 44,770 & $1,906,588$ \\
\hline 5 & $4,479,256$ & $5,474,071$ & 235,441 & $4,938,513$ \\
\hline Total & $6,278,696$ & $6,999,521$ & 321,252 & $13,290,321$ \\
\hline
\end{tabular}

As can be seen from Table A3.1, the employers we were able to classify by their ownership and sector of economic activity not only comprise more than half of all observations but they are also much more likely to be present in all five databases (ranging from 71.3 percent of the total for private firms to 78.2 percent for government entities and state-owned enterprises. Less than 3 percent of all observations on classified employers pertain to entities present on only one year. In contrast more than 7 percent of observations on unclassified employers (income-generating sources in the data) come from those observed in only one year and just about 37 percent survive for all five years. As explained in more detail in Section III of the main text, this means that we have successfully eliminated many paper companies that actually do not employ anybody but are simply a vehicle for tunneling and laundering money - a very serious problem in the Russian economy at the time and even today. Thus limiting the sample to only those employers we have been able to classify actually may be thought of increasing the representativeness of our estimations inasmuch as we are interested in real, not fake companies and their culture of transparency.

We have assigned sectors of economic activity to all classified employers by looking up their information from open sources. The list of the sectors and the breakdown of the sample (for all observations and separately for car owners) is shown in Table A3.2. In the analysis we drop observations on the "other" sector (which includes the self employed and employers whose sector of activity we were unable to classify even though we found their information and were able to determine ownership) as well as on private security firms (primarily because of difficulties in distinguishing real car ownership for consumption purposes from professionally required car ownership in this very specific sector of the Russian economy). We use the remaining 17 sector assignment dummies 
(less federal government, city and local government and law enforcement when we limit analysis to the private sector) in cross-section regressions to control for sector-specific differences in propensity to report earnings more or less transparently as well as other possible sector-specific factors that can affect our estimations.

Table A3.2 Sectors of economic activity

\begin{tabular}{|c|c|c|c|c|}
\hline \multirow[b]{2}{*}{ Sectors } & \multicolumn{2}{|c|}{ All observations } & \multicolumn{2}{|c|}{ Car owners } \\
\hline & $\begin{array}{l}\text { Number of } \\
\text { observations }\end{array}$ & $\begin{array}{l}\text { Fraction in } \\
\text { total }\end{array}$ & $\begin{array}{l}\text { Number of } \\
\text { observations }\end{array}$ & $\begin{array}{l}\text { Fraction in } \\
\text { total }\end{array}$ \\
\hline Banking, finance, insurance & $1,398,132$ & 10.27 & 121,368 & 14.93 \\
\hline Federal government & 311,284 & 2.29 & 30,673 & 3.77 \\
\hline City and local government & 256,657 & 1.89 & 13,683 & 1.68 \\
\hline Law enforcement & 463,501 & 3.40 & 47,743 & 5.87 \\
\hline Higher education and research & $1,420,080$ & 10.43 & 75,184 & 9.25 \\
\hline Secondary education & 604,329 & 4.44 & 22,927 & 2.82 \\
\hline Health care and medical services & 905,089 & 6.65 & 47,923 & 5.89 \\
\hline Mass media & 185,151 & 1.36 & 16,451 & 2.02 \\
\hline Construction & $1,084,589$ & 7.97 & 65,722 & 8.08 \\
\hline Utilities & 658,756 & 4.84 & 27,658 & 3.40 \\
\hline Transportation & 850,891 & 6.25 & 49,701 & 6.11 \\
\hline Wholesale and retail trade & $1,120,370$ & 8.23 & 68,463 & 8.42 \\
\hline Manufacturing & $1,905,720$ & 14.00 & 92,641 & 11.39 \\
\hline Sports and entertainment & 259,967 & 1.91 & 14,351 & 1.77 \\
\hline Services & $1,148,596$ & 8.44 & 65,982 & 8.12 \\
\hline Communications, IT & 416,218 & 3.06 & 23,264 & 2.86 \\
\hline Non-education not-for-profits & 337,588 & 2.48 & 10,159 & 1.25 \\
\hline Private security & 154,137 & 1.13 & 10,356 & 1.27 \\
\hline Other* & 132,814 & 0.98 & 8,786 & 1.08 \\
\hline
\end{tabular}

*Including self employed and unknown. 